\title{
Design and development of a Building Façade Integrated Asymmetric Compound Parabolic Photovoltaic concentrator (BFI-ACP-PV)
}

\author{
Wei Lu, ${ }^{\mathrm{a}}$ Y Yupeng Wu $\mathrm{u}^{\mathrm{b}, *}$ and Philip Eames ${ }^{\mathrm{c}}$ \\ aSchool of Energy and Power Engineering, University of Shanghai for Science and \\ Technology, 200093 P.R.China \\ ${ }^{b}$ Department of the Architecture and Built Environment, Faculty of Engineering, University of \\ Nottingham, Nottingham NG7 2RD, UK \\ ${ }^{\circ}$ Centre for Renewable Energy Systems Technology, Loughborough University, \\ Loughborough LE11 3TU, UK
}

\begin{abstract}
*Corresponding Author: Tel: +44 (0) 11574 84011; emails: Yupeng.Wu@nottingham.ac.uk, Jackwuyp@googlemail.com
\end{abstract}

\begin{abstract}
Building Integrated PV and Concentrating PV can generate electricity onsite and provide savings in materials and electricity costs, as well as protecting buildings from weather. In this paper, a novel truncated stationary Asymmetric Compound Parabolic Photovoltaic concentrator with a geometric concentration ratio of 2.0 has been designed and experimental characterised. The designed system is suitable for building façade application, especially for vertical façade. It has wide acceptance half angles of $0^{\circ}$ and $55^{\circ}$, this acceptance angle range enables the concentrator to operate year-round at its geometric gain in most of the UK and EU climatic condition. A comprehensive indoor test was carried out to evaluate the electrical and thermal characterisation of the developed Building Façade Integrated Asymmetric Compound Parabolic Photovoltaic concentrator (BFI-ACP-PV) system, and also the factors that affect the power output of the developed system. The experimental results showed that the developed BFI-ACP-PV system has the potential to increase the power output per unit solar cell area by a factor of 2 , when compared with a non-concentrating PV system. Subsequently, a Phase Change Material (PCM) system was integrated to the rear of the BFI-ACP-PV system to moderate the PV temperature rise and maintain good solar to electrical conversion efficiency. It was found out that the electrical conversion efficiency for the BFI-ACP-PV coupled PCM system was increased by over $5 \%$ compared with a similar system with no PCM integrated at the rear, when the incident solar radiation intensity was $280 \mathrm{~W} / \mathrm{m}^{2}$, this value increased by over $10 \%$ for an incident solar radiation intensity of $670 \mathrm{~W} / \mathrm{m}^{2}$.
\end{abstract}

Key words: Building Façade Integrated Asymmetric Compound Parabolic PV concentrator; Phase Change Materials; Power Output; Solar to electrical conversion efficiency; electrical power losses.

\section{Introduction}

It is widely accepted that photovoltaic (PV) solar energy has the potential to meet a significant proportion of the world's future energy needs. Low efficiencies with relative high costs comparing with other power generation technologies remain barriers to wide scale adoption of PV. Optical concentrator systems have the potential to increase the solar radiation intensity and efficiency of the solar collector system [1]. The increased solar radiation intensity on the PV system may reduce the system cost, in addition it produces an interesting architectural feature [2]. However, the output power of silicon based PV systems decrease with increasing PV module temperature. The thermal management of PV systems is therefore important. PV cooling can reduce PV module temperatures and thus increase solar to electrical conversion efficiency, this can be achieved using a range of different approaches, for example an air gap/duct to the rear of the PV panel, combination with low temperature solar thermal collectors and the use of Phase Change Materials (PCM) with appropriate phase transition temperatures [3-7]. Moshfegh and Sandberg [8] used both CFD 
predictions and experimental measurements as complementary techniques to analyse the performance of air flow and heat transfer in an air gap behind PV panels. Brinkworth [9] reported an optimum value of $P V$ air duct design, such that when the $L / D$ ( $L$ was the length of PV array at the front surface of the duct, D was the hydraulic depth of the duct) ratio was about 20, the minimum PV temperature was obtained. They also indicated that this value was not significantly affected by the slope of the PV array. Garg and Adhikari [10,11] developed a computational model for predicting the transient performance of a conventional PV-Thermal air heating collector using typical climate data for New Delhi, India. Tripanagnostopoulos et al [12] investigated the performances of PV stand alone, PV-air thermal collector, and PV- water thermal collector, systems respectively. For these $3 \mathrm{PV}$ systems it was found that there were no significant PV module temperature differences. The electrical efficiency of the air PV-Thermal system increased by $1.6 \%$ compared with that of the PV standalone system. An increase of $3.1 \%$ was measured for the water PV-Thermal system compared with the PV standalone system. Huang et al [13] conducted an experimental evaluation of the potential of using PCMs for PV cooling. It was found that RT25 had a better thermal control potential than GR40 for the PV panel tested. They also conducted experimental tests embedding different numbers and types of fins in to the PCM to improve the effect heat transfer to the PCM and the thermal management provided to the PV panel. Huang et al [14] reported the development of a three-dimensional numerical model which they used to simulate a phase change material container linked to a PV system used to control the temperature rise of the PV cells. Hasan et al. [15] integrated 5 different types of PCM with melting temperatures of $25 \pm 4^{\circ} \mathrm{C}$ and heat of fusion between 140 and $213 \mathrm{~kJ} / \mathrm{kg}$. A maximum temperature reduction of $18^{\circ} \mathrm{C}$ was achieved for 30 min while $10^{\circ} \mathrm{C}$ temperature reduction was maintained for $5 \mathrm{~h}$ at $1000 \mathrm{~W} / \mathrm{m}^{2}$ insolation. Biwole et al. [16] carried out numerical study of combined PV-PCM system. It was found that adding a PCM with a melting temperature of $26^{\circ} \mathrm{C}$ on the back of a solar panel can maintain the panel's operating temperature under $40^{\circ} \mathrm{C}$ for 80 min under a constant solar radiation of $1000 \mathrm{~W} / \mathrm{m}^{2}$. Park et al., [17] conducted outdoor test of PV-PCM system and concluded that the optimised melting temperature for $\mathrm{PCM}$ was determined to be $25^{\circ} \mathrm{C}$. The electric power generation was increased by $1.0-1.5 \%$ compared to that of the conventional PV module. Hasan et al., [18] used Calcium chloride hexahydrate $\mathrm{CaC}_{12}-6 \mathrm{H}_{2} \mathrm{O}$ and Eutectic of Capric-Palmitic acid for PV cooling. Browne et al. [19] developed a novel PV/T/PCM system that generates electricity, stores heat and pre-heats water. Moreover, some researches have been performed to study the possibilities of using the waste heat of PV cells, e.g. driving methanol decomposition for combined cycle [20] or acting as heat source for heat pumps [21,22]. A few researchers also attempted to combine concentrating PV and PCM to increase the solar radiation intensity on PV surface and also for PV thermal management. Maiti et al. [23] integrated a PCM with a melting temperature of approximately $56-58^{\circ} \mathrm{C}$ to the rear of a $\mathrm{V}$-trough $\mathrm{PV}$ system. During the indoor tests, when PCM integrated, the PV temperature could be maintained at $65-68^{\circ} \mathrm{C}$ for 3 hours whereas in its absence the temperature rose beyond $90^{\circ} \mathrm{C}$ within 15 min under an unrealistic irradiation of $2300 \mathrm{~W} / \mathrm{m}^{2}$. Emam et al [24] [25] numerically investigated the thermal performance of a parabolic trough combined PCM system. Su et al [26] investigated the effects of phase change material (PCM) cooling for a tracking-integrated concentrating photovoltaic-thermal (CPV-T) system. There is a potentially 10\% increase of the electrical power output when compared with similar concentrating system with water cooling. Sharma et al. [27] experimentally investigated the effect of using PCM with a melting temperature of $42^{\circ} \mathrm{C}$ on a Building-Integrated concentrated PV. An increase in relative electrical efficiency by $7.7 \%$ with PCM incorporation at solar radiation intensity of $1000 \mathrm{~W} / \mathrm{m}^{2}$ was observed. Although the designed Concentrated PV system is more suitable for vertical façade, the system was tested under horizontal location. The effect of nature convection on heat transfer within the PCM under melting stage would be difficult to be evaluated. Then, Sharma et al [28] proposed to incorporate micro-fins, Phase Change Material and Nanomaterial Enhanced PCM for Building-Integrated Concentrated PV. Experimental tests were carried out to evaluate the simulated PV performance with the various thermal management systems integrated. The integration of $\mathrm{PCM}$ demonstrated a temperature reduction 0 f $10^{\circ} \mathrm{C}$, 
when compared with the system without the PCM. In addition, there are some development in novel building integrated concentrating PV window systems, the developed systems can be used for electricity generation and also daylight control recently [29-31].

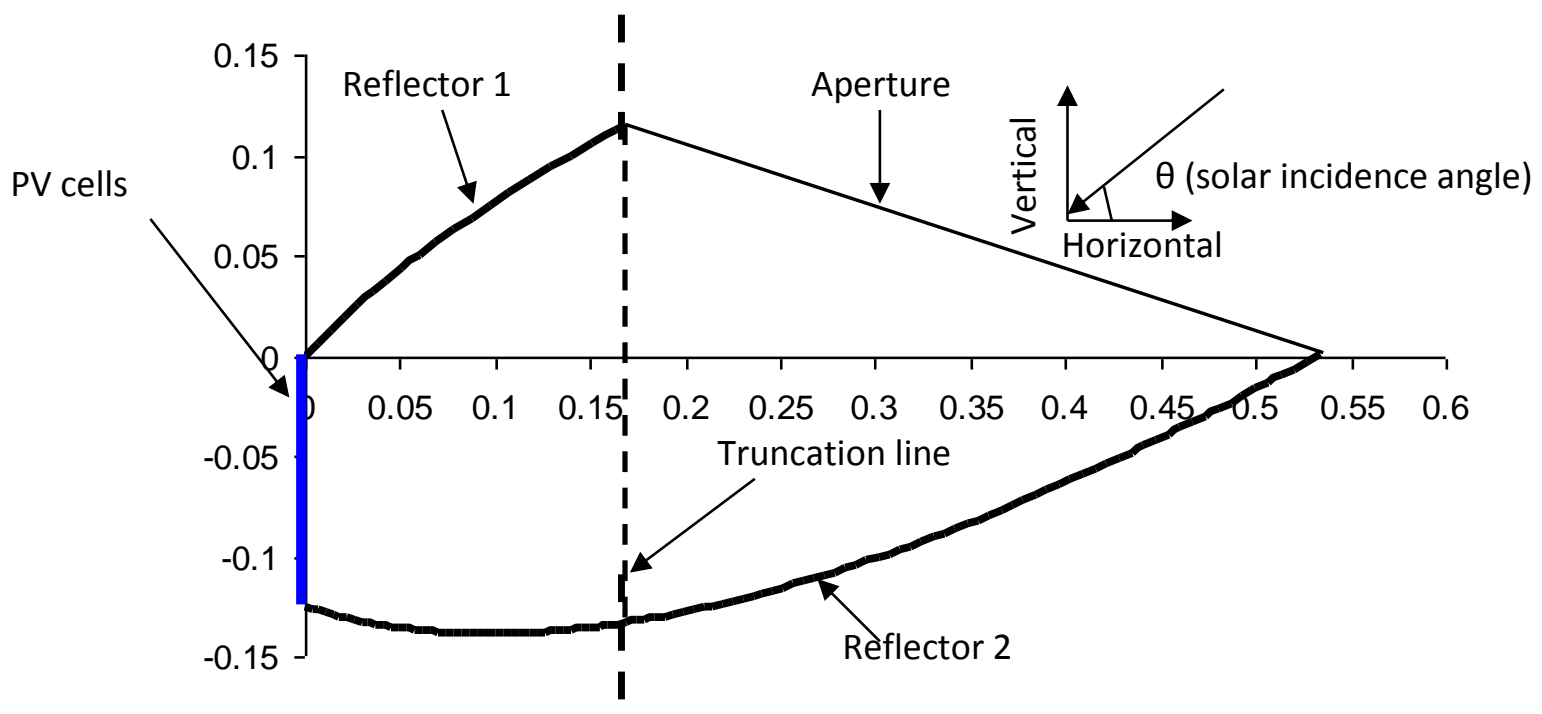

Figure $1 \mathrm{BFI-ACP-PV}$ system with acceptance-half angle of $0^{\circ}$ and $55^{\circ}$, all dimensions in metres.

This paper presents work aimed at developing a novel stationary concentrating PV façade system, which can minimise the use of PV systems while maintaining good solar energy capture and electrical conversion efficiency. Meanwhile, a Phase Change Material (PCM) system was integrated to the rear of the concentrating PV system to moderate the temperature rise of the PV. The developed concentrating PV combined PCM system therefore can be used for electricity generation and also store the excessive heat in daytime and potentially for later use. A low concentration non-imaging air filled truncated non-tracking Building Integrated Asymmetric Compound Parabolic Photovoltaic Concentrator (BFI-ACPPV) system, which has a geometric concentration ratio of 2.0 and acceptance half angles of $0^{\circ}$ and $55^{\circ}$, has been designed and experimentally studied. This developed stationary BFIACP-PV system can operates year-round at its geometric gain in most of the UK and EU climatic condition. A comprehensive characterisation of the developed BFI-ACP-PV/PCM and its counterpart non-concentrating PV were investigated under indoor environmental conditions. Both electricity and thermal behaviour were evaluated under various solar radiation intensities. The temperature dependency of solar to electrical conversion efficiency was also conducted. Finally, the power loss of the BFI-ACP-PV system was also analysed. A schematic illustration showing the cross section of the reflector profiles, illustrating the truncation made is shown in Figure 1.

\section{BFI-ACP-PV/PCM system design and construction}

Based on a detailed optical and heat transfer analysis [32], a prototype of a truncated BFIACP-PV/PCM system was designed and constructed and is shown in Figure 2. The components of this system included the PV absorber, reflectors, reflector supports, PCM material, PCM container, aperture cover and support frame. The chosen reflector material, the specifications of the selected PV and the thermophysical property of the selected PCM are detailed in the following sections. 


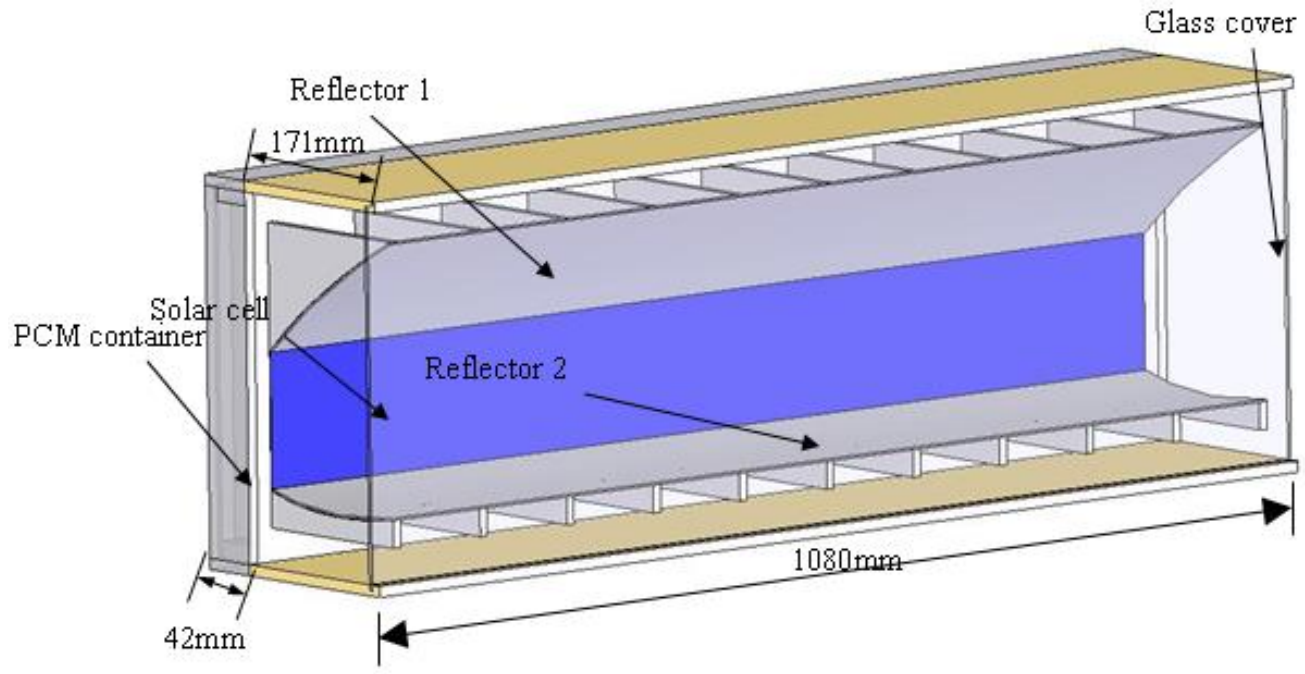

Figure 2 A 3D diagram illustrating the BFI-ACP-PV system

\subsection{Reflective material, reflector support and back plate employed for the BFI-ACP-PV system}

The reflectors require a high reflectivity to minimise optical losses, with good durability to minimise environmental degradation. The Miro 4270 KKSP form of the Miro-Sun product line, produced by the Alanod Company, is an aluminum-based material with a total reflectivity in the visible range of 0.95 . It also gives a high reflectivity for wavelengths in the range of 850 $900 \mathrm{~nm}$ and is suitable for use with PV materials. $0.4 \mathrm{~mm}$ thick Alanod Miro $4270 \mathrm{KKSP}$ reflective aluminium sheets were used as the reflectors for the experimental prototype system.

Two profiles of reflector support were designed and manufactured from $8 \mathrm{~mm}$ thick aluminium, which had sufficient thickness, stiffness and strength to bond to and support the reflectors. All the profile data points were transferred to 'AUTOCAD', and then machined using a 'CNC' machine. An $8 \mathrm{~mm}$ thick aluminium plate with $1040 \mathrm{~mm}$ long by $334.5 \mathrm{~mm}$ wide was chosen to provide the base for the PV cells and reflector supports. Twenty-two slits, 2 $\mathrm{mm}$ deep and $4 \mathrm{~mm}$ wide were machined into the aluminium back plate to accommodate the reflector supports. The distance between the central line of each slit was $100 \mathrm{~mm}$ along the length of the back plate with spaces $32 \mathrm{~mm}$ wide on the upper and lower edges of the aluminium back plate to install a weather proof system cover. Gaps $20 \mathrm{~mm}$ wide on both the left and right side edges of the back plate were left for the weather proof cover.

\subsection{PV selection, PV cell interconnection, and Encapsulation of PV cells strings}

BP Saturn laser grooved buried contact solar cells [33] were used for the prototype experimental system. The detailed specifications of the selected solar cells are shown in Table 1 [33]. Six BP Saturn solar cells were series connected in one strip for the prototype BFI-ACP-PV system. Copper PV tabbing $0.1 \mathrm{~mm}$ thick and $2.0 \mathrm{~mm}$ wide were used to interconnect the solar cells. A silicon elastomer (Sylgard-184) was used to encapsulate and attach the solar cells to the aluminium back plate, to prevent short circuit between the PV cells and the aluminium back plate, and also to protect the PV cells from the environment. 
Table 1: Specification of BP Saturn laser grooved buried contact solar cell (Cell type: CellMC-S S115) [33]

\begin{tabular}{c|c}
\hline Parameter & Values \\
\hline Cell dimensions & $125 \mathrm{~mm} \times 125 \mathrm{~mm}$ \\
\hline $\mathrm{V}_{\mathrm{oc}}$ & $610.1 \mathrm{mV}$ \\
\hline $\mathrm{I}_{\mathrm{sc}}$ & $5.595 \mathrm{~A}$ \\
\hline $\mathrm{I}_{\text {load }}$ & $5.502 \mathrm{~A}$ \\
\hline $\mathrm{P}_{\max }$ & $2.688 \mathrm{~W}$ \\
\hline$\eta_{\max }$ & $17.42 \%$ \\
\hline $\mathrm{ff}$ & $78.76 \%$
\end{tabular}

Experimental tests were carried for one full size BP Saturn solar cell with and without a Sylgard 184 coating on the front surface at different solar radiation intensities to investigate the effect of Sylgard-184 front coating on the cell performance. The solar cells were illuminated under a highly collimated Model SS $1.6 \mathrm{~kW}$ solar simulator manufactured by Sciencetech Company. The measured short circuit current, open circuit voltage and maximum power point the solar cells are presented Table 2. It can be seen that the full size BP Saturn solar cell had a decrease in short circuit current of $6 \%$ when coated with Sylard184 on the front surface, compared to no coating for similar radiation levels. The open circuit voltages were almost the same in both cases. Although the coating reduced the short circuit current of the solar cell, the reduction in maximum power output was only about $1 \%$.

Table 2 The short circuit current, open circuit voltage and maximum power point for a solar cell tested with and without Sylgard 184 coating on the front surface for different solar radiation intensities.

\begin{tabular}{c|c|c|c|c}
\hline & $\begin{array}{c}\text { Solar radiation } \\
\text { intensity }\left(\mathbf{W} / \mathbf{m}^{2}\right)\end{array}$ & Isc (A) & Voc (V) & MPP (W) \\
\hline \multirow{4}{*}{ uncoated solar cell } & 555 & 2.20 & 0.576 & 0.90 \\
\cline { 2 - 5 } & 714 & 2.89 & 0.562 & 1.08 \\
\cline { 2 - 5 } & 848 & 3.45 & 0.562 & 1.21 \\
\cline { 2 - 5 } & 926 & 3.78 & 0.560 & 1.28 \\
\hline \multirow{3}{*}{$\begin{array}{c}\text { Front surface } \\
\text { coated solar cell }\end{array}$} & 555 & 2.08 & 0.576 & 0.88 \\
\cline { 2 - 5 } & 714 & 2.70 & 0.567 & 1.06 \\
\cline { 2 - 5 } & 848 & 3.12 & 0.564 & 1.20 \\
\cline { 2 - 5 } & 926 & 3.56 & 0.560 & 1.27 \\
\hline
\end{tabular}

\subsection{Phase change material selection and container design}

The standard characterising temperature of $\mathrm{PV}$ cells is $25^{\circ} \mathrm{C}$ [34]. The appropriate phase change material should therefore have a melt temperature around $25^{\circ} \mathrm{C}$ and also to allow discharge in the summer be higher than the summer average ambient air temperature in the UK. RT27 solid to liquid phase change material which has a melting temperature of $27^{\circ} \mathrm{C}$ was chosen for this study. The characteristics of the PCM RT 27 are shown in Table 3 [35].

A PCM container with a regular rectangular cross section which was both simple to assemble and also suitable for building façade integration was selected. The aluminium back plate of the BFI-ACP-PV was used for the front cover of the PCM container to obtain good thermal contact between the solar cell and the PCM container and heat transfer to the PCM. The required volume of the PCM and thus the depth of the PCM container depended on the incident solar radiation intensity, the duration of the solar radiation, the heat loss from the BFI-ACP-PV/PCM system and the thermal capacity of the PCM material. The PCM container depth was estimated to be $4.2 \mathrm{~cm}$ for the prototype PCM [36]. The interior dimensions of the prototype PCM container were $1040 \mathrm{~mm}$ x $431.9 \mathrm{~mm}$ x $42 \mathrm{~mm}$. 
Table 3: Thermophysical properties of the chosen phase change material RT27 [35]

\begin{tabular}{c|c}
\hline Property & RT 27(liquid) \\
\hline Main component & n-paraffin \\
\hline Latent heat of fusion $\left(\mathrm{kJ} \mathrm{kg}^{-1}\right)$ & $179($ Temp from \\
Melting temperature $\left({ }^{\circ} \mathrm{C}\right)$ & $19^{\circ} \mathrm{C}$ to $\left.34^{\circ} \mathrm{C}\right)$ \\
Density $\left(\mathrm{kg} \mathrm{m}^{-3}\right)$ & 28 \\
Solid 870 at $15^{\circ} \mathrm{C}$ \\
Specific heat capacity $\left(\mathrm{kJ} \mathrm{kg}^{-1} \mathrm{~K}^{-1}\right)$ & 1.8 Solid $/ 2.4$ liquid \\
Heat conductivity $\left(\mathrm{W} \mathrm{m}^{-1} \mathrm{~K}^{-1}\right)$ & 0.2 \\
Flash point $\left({ }^{\circ} \mathrm{C}\right)$ & 164 \\
Volume expansion & $16 \%($ at $\triangle \mathrm{T}=55 \mathrm{~K})$ \\
\hline
\end{tabular}

\subsection{System enclosure and cover (Weather proof cover)}

In most solar energy applications, glass is used as a protective aperture cover due to its optical and mechanical properties. Compared with high iron content glass, low iron glass contains less $\mathrm{Fe}_{2} \mathrm{O}_{3}$ and absorbs less of the incident solar energy. A $4 \mathrm{~mm}$ thick low iron glass sheet was used for the front cover of the BFI-ACP-PV system. A $5 \mathrm{~mm}$ thick Perspex sheet was used at the reflector end for the side covers of the BFI-ACP-PV system to reduce the risk of shading of the PV system for non-perpendicular solar incidence angles. $20 \mathrm{~mm}$ thick wooden boards were used for the upper and lower supporting structure of the system enclosure. The dimensions of the upper and lower wooden frames were all $1060 \mathrm{~mm}$ long by 196.2mm wide.

\section{Indoor experimental characterisation}

Extensive indoor experimental characterisation of truncated BFI-ACP-PV and BFI-ACP-PV /PCM systems were undertaken for a range of incident solar radiation intensities using a developed collimated solar simulator (illumining area $0.6 \mathrm{~m}$ X 1m) [36]. An electronic Keithley 2430 source-meter was used in the following tests to measure the current and voltage of the solar cells, and the system thermal performance was measured by a Keithley 2750 data acquisition system. Figure 3 shows the BFI-ACP-PV system under test using the developed solar simulator.

Important factors describing the performance of a solar concentrator are the fill factors and efficiency and also maximum power point. The fill factors ( ff) can be calculated by Equation 1,

$$
f f=\frac{I_{\max } V_{\max }}{I_{s c} V_{o c}}
$$

The maximum power point (MPP) can be calculated using Equation 2,

$$
M P P=I_{\max } V_{\text {max }}
$$

The PV efficiency $(\eta)$ is given as follows Equation 3,

$$
\eta=\frac{P_{\max }}{G A}
$$

Where, $I_{\max }$ and $I_{s c}$ are the current at maximum power point and short circuit current respectively, $V_{\max }$ and $V_{o c}$ are the voltage at the maximum power point and open circuit voltage respectively, $G$ is the incident solar radiation and $A$ is the effective solar cell area. 


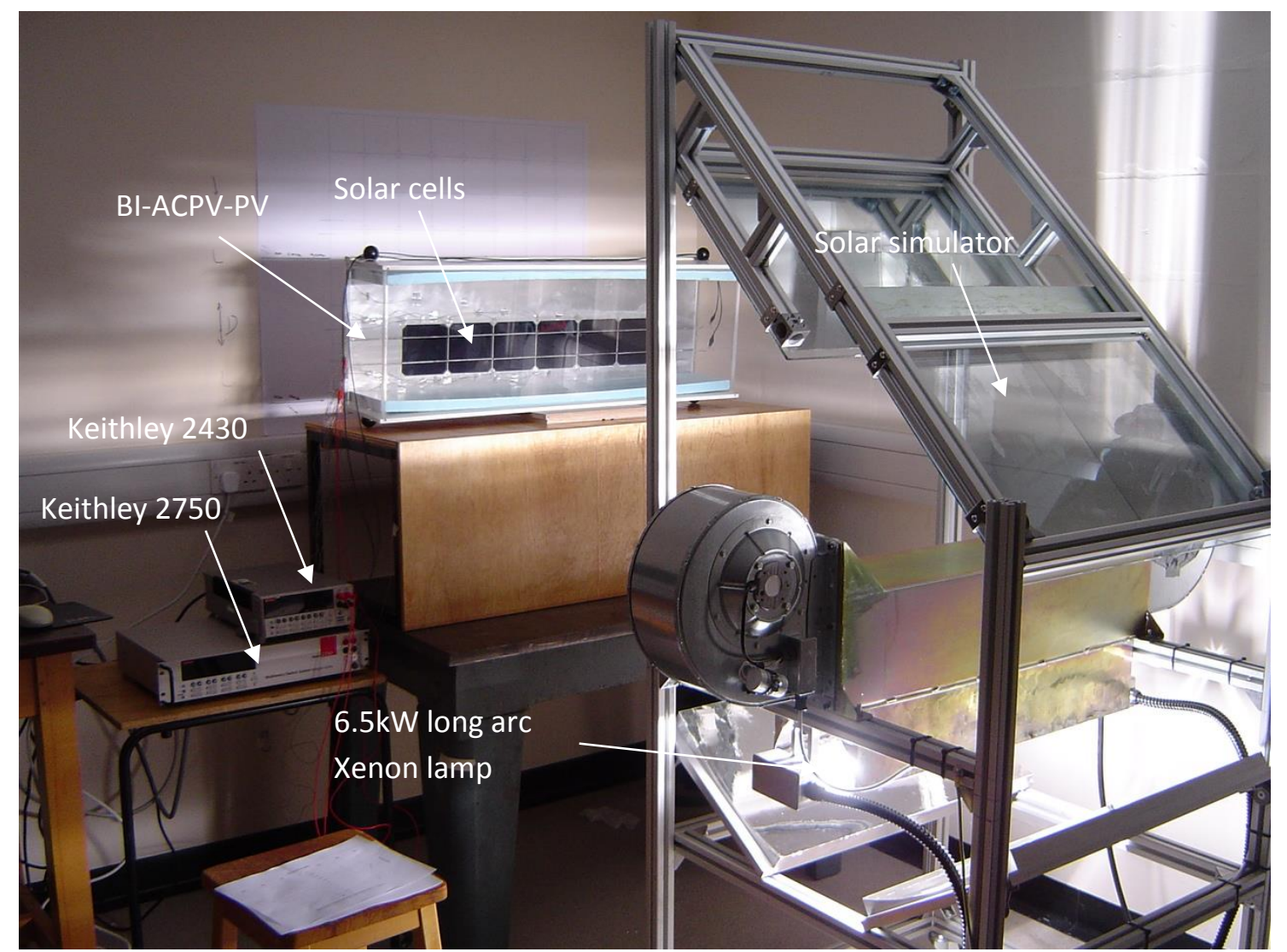

Figure 3 Experimental characterization of the BI-ACPC- PV system using the developed solar simulator

\subsection{Measured I-V and thermal behaviour of the BFI-ACP-PV system}

The thermal behaviour of the BFI-ACP-PV was investigated by illuminating the system using the solar simulator until it reached steady state. The thermocouple positions on the front of the aluminium back plate and rear of the reflector surface are shown in Figures 4. Thermocouples T1 to T8 were located on the front of the aluminium back plate, thermocouples T9 to T14 were used to measure the temperatures on the rear surface of reflectors 1 and 2 . Thermocouples T15 to T18 were used to measure the temperature on the rear surface of the aluminium back plate. T19 and T20 were used to measure the front glass cover and ambient temperatures, respectively. Temperature readings were taken every 30 seconds. The incident solar radiation intensities used were $69 \mathrm{~W} / \mathrm{m}^{2}, 280 \mathrm{~W} / \mathrm{m}^{2}$ and $670 \mathrm{~W} / \mathrm{m}^{2}$, which represented the low, medium and high solar radiation intensities that could be obtained with the developed solar simulator. An air conditioning system set to $20^{\circ} \mathrm{C}$ was used to control the ambient room temperature.

When the BFI-ACP-PV system was tested at incident solar radiation intensities of 69 , 280 and $670 \mathrm{~W} / \mathrm{m}^{2}$ with a solar incidence angle of $0^{\circ}$, the temperatures of the BFI-ACP-PV system reached steady state after approximately 200 minutes for all radiation levels. The measured steady state temperatures for the BFI-ACP-PV and its counterpart nonconcentrating system are presented in Table 3 . When the incident solar radiation intensity was $69 \mathrm{~W} / \mathrm{m}^{2}$, the measured steady state average solar cell temperature was $25.8^{\circ} \mathrm{C}$, which was $4.6^{\circ} \mathrm{C}$ higher than that of the ambient. It is also approximately $1^{\circ} \mathrm{C}$ higher than that of the non-concentrating system. When the incident solar radiation intensity was 280 and $670 \mathrm{~W} / \mathrm{m}^{2}$, the measured average solar cell temperatures were approximately 17 and $38^{\circ} \mathrm{C}$ higher than that of the ambient, respectively, they were approximately 3 and $7^{\circ} \mathrm{C}$ higher than those of the non-concentrating system, which being considerably higher than the Standard Characterising Temperature of PV leads to a significant reduction in power output from the BFI-ACP-PV system. 


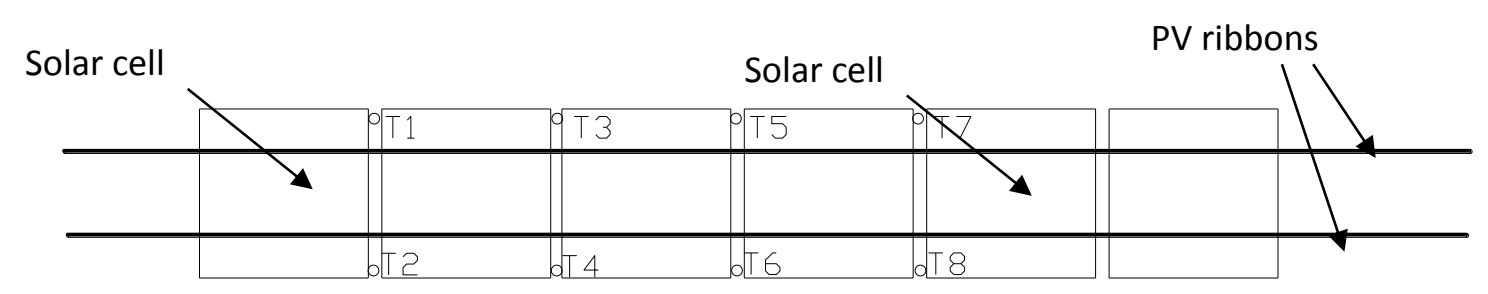

(a) Thermocouples locations on the aluminium back plate for the BFI-ACP-PV system

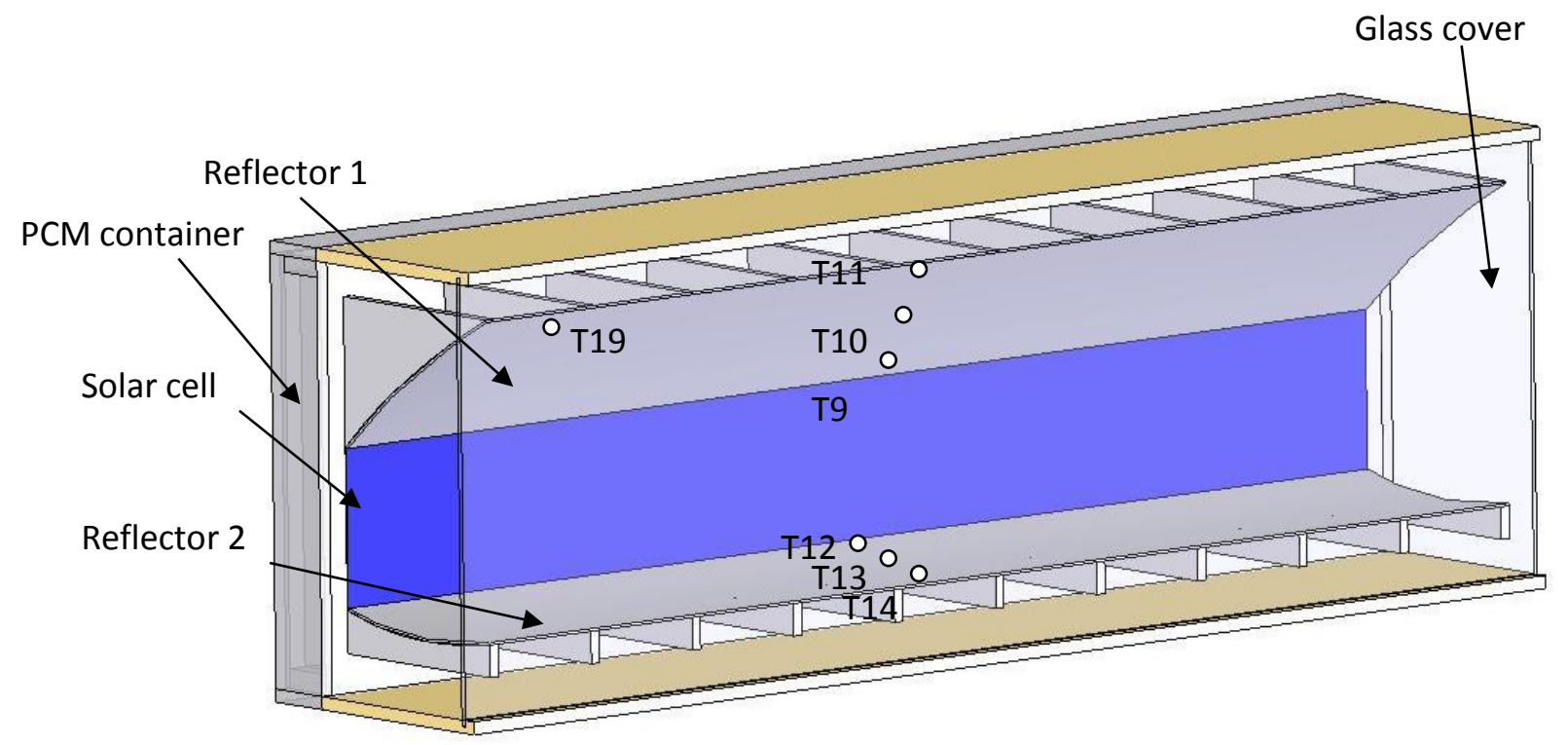

(b) Thermocouple locations on the rear surface of the reflectors for the BFI-ACP-PV system

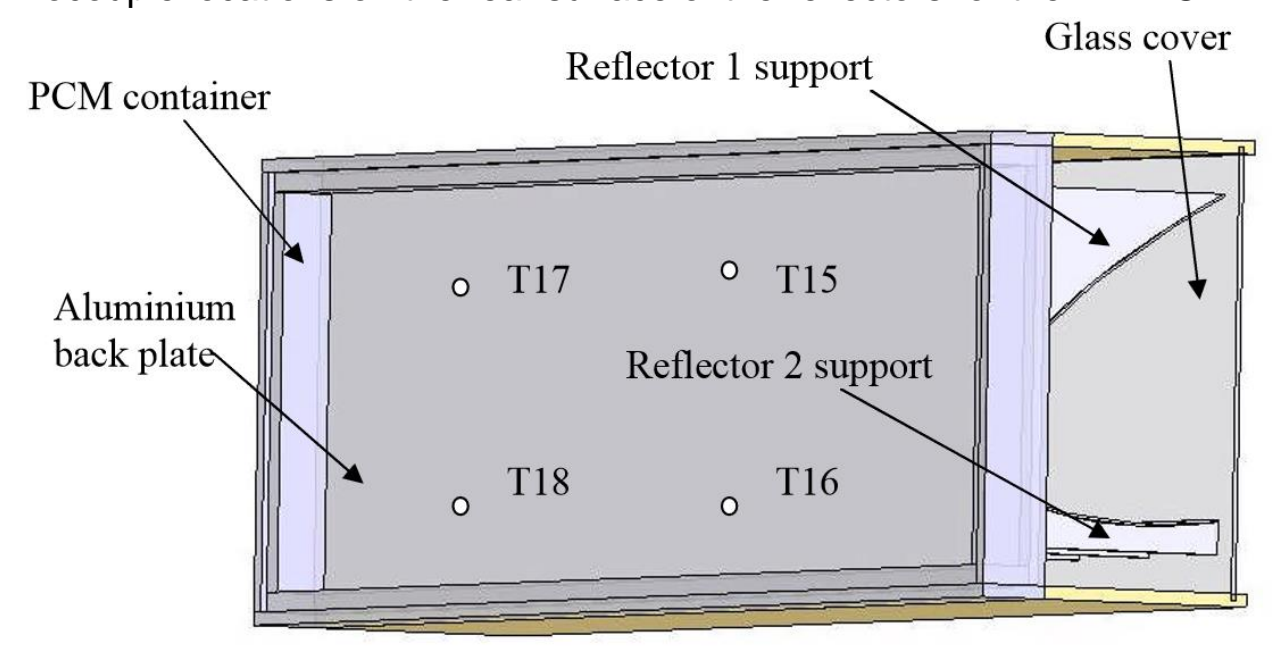

(c) Thermocouple locations on the rear surface BFI-ACP-PV back plate

Figure 4. Schematic diagrams showing the locations of the thermocouples 
Table 3: Measured temperature of the BFI-ACP-PV and its counterpart non-concentrating $P V$ for different incident solar radiation intensities.

\begin{tabular}{|c|c|c|c|c|}
\hline & \multicolumn{3}{|c|}{ Incident solar radiation intensities } \\
\hline & & $69 \mathrm{~W} / \mathrm{m}^{2}$ & $280 W / m^{2}$ & $670 \mathrm{~W} / \mathrm{m}^{2}$ \\
\hline \multirow{5}{*}{ BFI-ACP-PV } & Ave. solar cell temp $\left({ }^{\circ} \mathrm{C}\right)$ & 25.8 & 40.0 & 62.5 \\
\hline & Reflector 1 temperature $\left({ }^{\circ} \mathrm{C}\right)$ & 25.3 & 38.2 & 58.6 \\
\hline & Reflector 2 temperature $\left({ }^{\circ} \mathrm{C}\right)$ & 25.9 & 39.7 & 63.5 \\
\hline & Measured front cover $\left({ }^{\circ} \mathrm{C}\right)$ & 22.8 & 31.1 & 49.5 \\
\hline & Ambient temperature $\left({ }^{\circ} \mathrm{C}\right)$ & 21.2 & 23.9 & 24.6 \\
\hline \multirow{3}{*}{$\begin{array}{c}\text { Non- } \\
\text { Concentrating } \\
\text { Counterpart }\end{array}$} & Ave. solar cell temp $\left({ }^{\circ} \mathrm{C}\right)$ & 24.6 & 37.0 & 55.1 \\
\hline & Measured front cover $\left({ }^{\circ} \mathrm{C}\right)$ & 23.2 & 32.3 & 50.4 \\
\hline & Ambient temperature $\left({ }^{\circ} \mathrm{C}\right)$ & 21.4 & 24.5 & 24.1 \\
\hline
\end{tabular}

The measured I-V characteristics and variation of instantaneous power with voltage of the BFI-ACP-PV system and its counterpart non-concentrating system tested at an average solar radiation intensity of $69 \mathrm{~W} / \mathrm{m}^{2}, 280 \mathrm{~W} / \mathrm{m}^{2}$ and $670 \mathrm{~W} / \mathrm{m}^{2}$ with solar incidence angles of $0^{\circ}$ are shown in Figures 5 and 6 , respectively. The short circuit current, open circuit voltage, maximum power output and fill factor of the BFI-ACP-PV and non-concentrating PV system are presented in Table 4. At an incident solar radiation intensity of 69 and $280 \mathrm{~W} / \mathrm{m}^{2}$, the maximum power output of the BFI-ACP-PV system was 1.29 and $3.51 \mathrm{~W}$, respectively. The I$V$ curve for the $670 \mathrm{~W} / \mathrm{m}^{2}$ solar radiation could not be obtained, this was due to the output current from the system being greater than $3 \mathrm{~A}$, which was above the upper limit of the measurement instrument. The ratio of the maximum power output was 1.74 between the BFI-ACP-PV and the non-concentrating system at solar radiation intensity of $69 \mathrm{~W} / \mathrm{m}^{2}$, and 1.33 at solar radiation intensity of $280 \mathrm{~W} / \mathrm{m}^{2}$. The BFI-ACP-PV has a geometric concentrating ratio of 2.0, therefore, the measured power output of the concentrating system indicated that significant additional power losses occurred for the BFI-ACP-PV system. This also can be seen from the solar to electricity conversion efficiency. The solar to electricity conversion efficiency of the BFI-ACP-PV system is lower than that of the non-concentrating system. When the solar incident radiation intensity is $280 \mathrm{~W} / \mathrm{m}^{2}$, the efficiency of the BFI-ACP-PV is approximately $6.7 \%$, it is significant lower than that of $10.1 \%$ for the non-concentrating system at the same solar radiation intensity. The power loss in the concentrating system is discussed in section 5 .

Table 4: Measured power output of the BFI-ACP-PV and its non-concentrating counterpart system

\begin{tabular}{c|c|c|c|c|c}
\cline { 2 - 6 } \multicolumn{2}{c}{ BFI-ACP-PV } & \multicolumn{2}{c}{ Non-Concentrating Counterpart } \\
\hline $\begin{array}{c}\text { Incident solar } \\
\text { radiation }\end{array}$ & $69 \mathrm{~W} / \mathrm{m}^{2}$ & $280 \mathrm{~W} / \mathrm{m}^{2}$ & $69 \mathrm{~W} / \mathrm{m}^{2}$ & $280 \mathrm{~W} / \mathrm{m}^{2}$ & $670 \mathrm{~W} / \mathrm{m}^{2}$ \\
\hline Isc (A) & 0.52 & 1.77 & 0.32 & 1.15 & 2.15 \\
\hline Voc (V) & 3.22 & 3.21 & 3.12 & 3.21 & 3.11 \\
\hline MPP (W) & 1.29 & 3.51 & 0.74 & 2.64 & 4.55 \\
\hline$f f$ & 0.77 & 0.618 & 0.737 & 0.714 & 0.680 \\
\hline$\eta(\%)$ & 10.0 & 6.7 & 11.5 & 10.1 & 7.2 \\
\hline
\end{tabular}




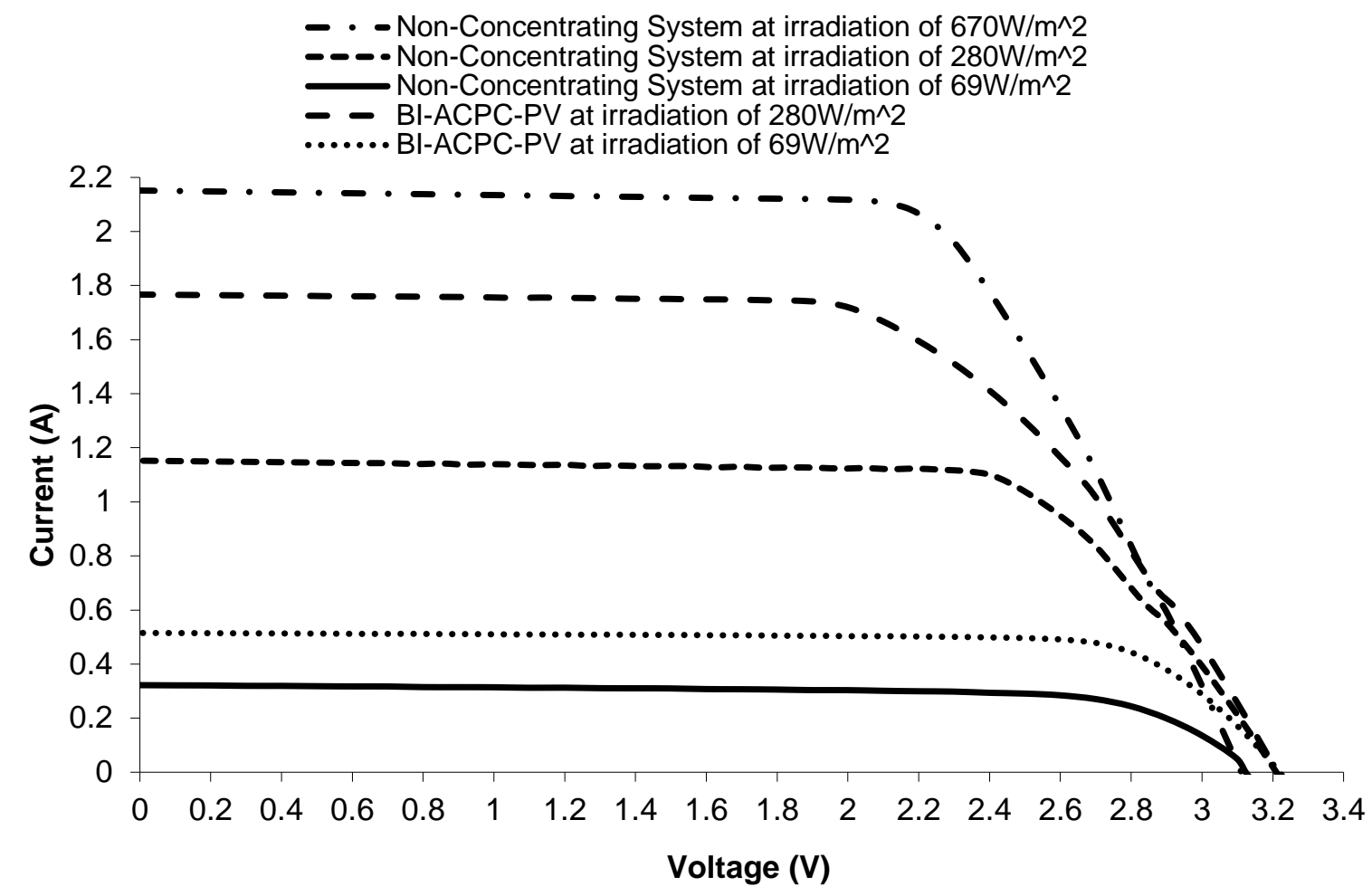

Figure $5 \mathrm{I}-\mathrm{V}$ characteristics of the BFI-ACP-PV system at radiation intensities of $69 \mathrm{~W} / \mathrm{m}^{2}$, $280 \mathrm{~W} / \mathrm{m}^{2}$ and $670 \mathrm{~W} / \mathrm{m}^{2}$

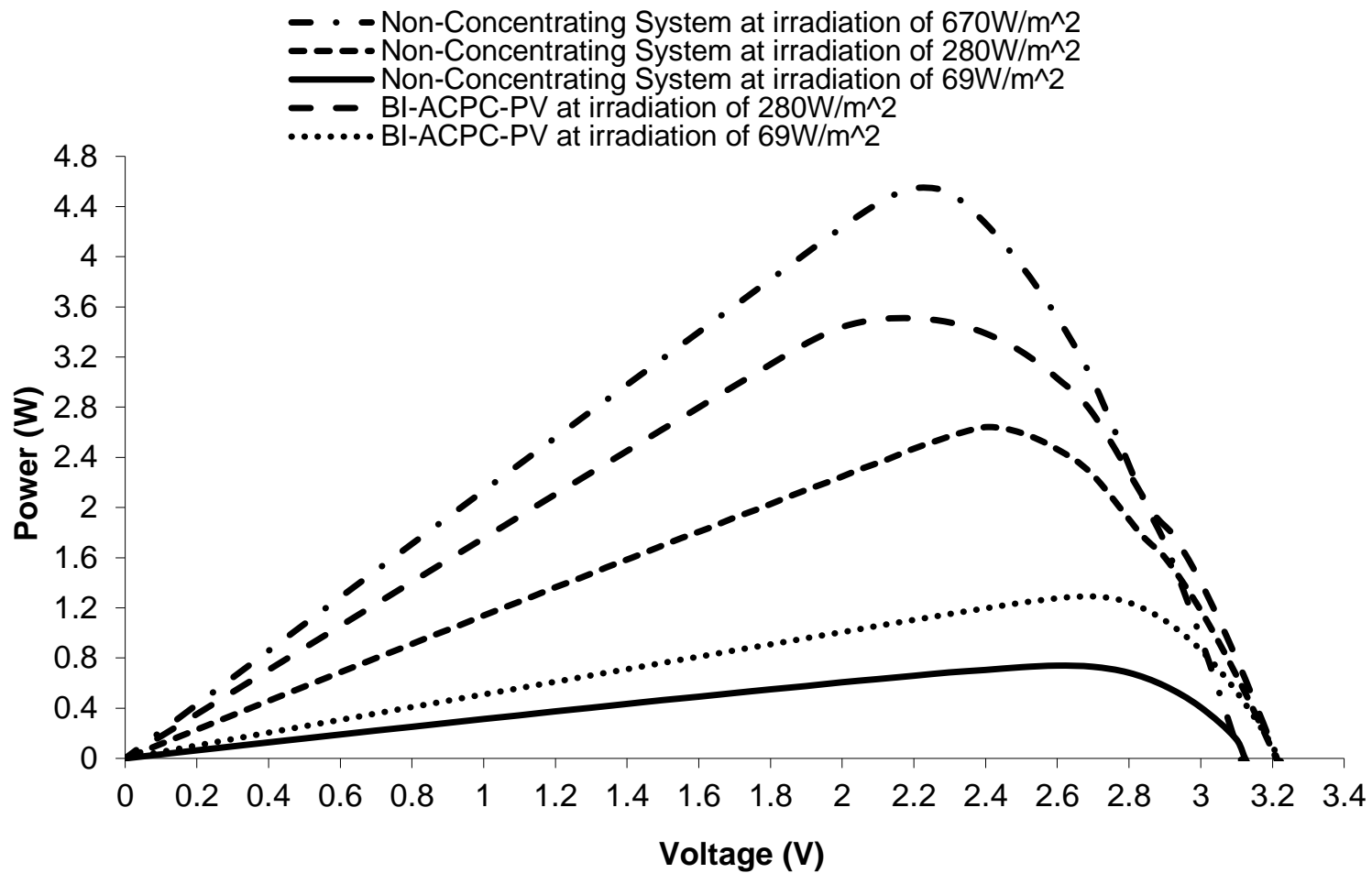

Figure 6 Variation of instantaneous power with sweep voltage for the BFI-ACP-PV system and non-concentrating system at radiation intensities of $69 \mathrm{~W} / \mathrm{m}^{2}, 280 \mathrm{~W} / \mathrm{m}^{2}$ and $670 \mathrm{~W} / \mathrm{m}^{2}$ 


\subsection{Measured I-V and thermal behaviours of the BFI-ACP-PV system combined with a PCM module for passive cooling}

The PCM container was filled with $9.08 \mathrm{~kg}$ of RT27, which was melted and poured into the cavity with $10 \%$ of the container volume left for expansion during phase change. The thermal performance of the BFI-ACP-PV/PCM system was investigated by illuminating the system with the solar simulator until it reached steady state. The applied experimental conditions used insolation of $280 \mathrm{~W} / \mathrm{m}^{2}$ and $670 \mathrm{~W} / \mathrm{m}^{2}$. The thermocouple positions on the front of the aluminium back plate and the rear of the reflector were the same as those for the BFI-ACPPV system with no PCM. A total of 20 thermocouples were inserted into the PCM container. The rationale behind the choice of the thermocouple location in the PCM was a desire to measure and analyse the temperature changes at the rear of the solar cells and reflector supports. Five thermocouple sets were chosen in the rear plate of the BFI-ACP-PV/PCM system. For each hole, four thermocouples were inserted at distances $2 \mathrm{~mm}, 14 \mathrm{~mm}, 26 \mathrm{~mm}$, and $38 \mathrm{~mm}$ from front plate. A detailed 3D sketch of the thermocouple insertion holes in the rear plate of the system is shown in Figure 7. Figure 8 illustrates the cross-sectional view showing locations of thermocouples T15 to T34 inside the PCM container. Four additional thermocouples were used to measure the temperature of the PCM rear cover of the BFIACP-PV /PCM system. The front glass aperture and the ambient room temperature were also recorded by another additional two thermocouples.

The measured variation of the average solar cell temperatures with time for the BFIACP-PV and BFI-ACP-PV/PCM system at a solar radiation intensity of $280 \mathrm{~W} / \mathrm{m}^{2}$ and $670 \mathrm{~W} / \mathrm{m}^{2}$ with incidence angle of $0^{\circ}$ are shown in Figures 9 and 10 . From Figure 9 , it can be seen that the average solar cell temperature on the front surface of the BFI-ACP-PV /PCM system was maintained below $34^{\circ} \mathrm{C}$ for 10 hours. The average solar cell temperature of the $\mathrm{BFI}-\mathrm{ACP}-\mathrm{PV} / \mathrm{PCM}$ system was steady at $33.2^{\circ} \mathrm{C}$, which was approximately $7^{\circ} \mathrm{C}$ lower than that of the BFI-ACP-PV with no PCM for the same incident solar radiation intensity, for more than 400 minutes, while the RT27 underwent phase change. Comparing this with the average solar cell temperature rise for the BFI-ACP-PV system with no PCM, the RT27 clearly delayed the PV cell temperature rise and demonstrated good potential to limit the temperature rise of a PV system. From Figure 10, at a solar radiation intensity of $670 \mathrm{~W} / \mathrm{m}^{2}$, RT27 within the BFI-ACP-PV /PCM system began to melt earlier than when tested at a solar radiation intensity of $280 \mathrm{~W} / \mathrm{m}^{2}$, and required a shorter time to complete the phase change process, only 4 hours compared to 10 hours for a radiation intensity of $280 \mathrm{~W} / \mathrm{m}^{2}$. Compared with the BFI-ACP-PV /PCM tested at a radiation intensity of $280 \mathrm{~W} / \mathrm{m}^{2}$, similar behaviour was found when the BFI-ACP-PV /PCM system underwent phase change, the average solar cell temperature was lower than that of the BFI-ACP-PV with no PCM. The average solar cell temperature on the front surface of the BFI-ACP-PV /PCM was maintained below $42^{\circ} \mathrm{C}$ for 4 hours.

From Figures 9 and 10, it also can be seen that the average temperature of PV cells in system with or without PCM increased significantly after illuminating. The average temperature of PV cells in the BFI-ACP-PV system increased sharply to as high as $40^{\circ} \mathrm{C}$ when the redundant heat can be released to the environment with the temperature difference. But the increase of average temperature of PV cells in the BFI-ACP-PV/PCM system becomes slow after the average temperature of PV cells was higher than $27^{\circ} \mathrm{C}$ as the PCM attached to the aluminium plate of PV cells began to melt, which absorbed more heat for PCM melting. When plenty of PCM melted, e.g. 250 mins for system at a solar radiation intensity of $280 \mathrm{~W} / \mathrm{m}^{2}$ and 90 mins for system at a solar radiation intensity of $670 \mathrm{~W} / \mathrm{m}^{2}$, natural convection can be formed effectively in PCM region (also shown in Figure 11 (250mins)) which has higher heat transfer ability, then the average temperature of PV cells reaches steady state values, the temperature of PV cells remained constant for several hours until most of PCM have been melted. Photographs and isotherms plotted from the measured temperatures during the phase change process for the BFI-ACP-PV/PCM system at times of 250,300. 400500 and 600mins are presented in Figure 11. The phase change can be clearly seen after the system was illuminated by the solar simulator for $250 \mathrm{mins}$, the RT27 adjacent to the aluminium plate on which the solar cells were mounted melted quicker 
than other region because solar cells releases redundant heat and the aluminium plate spread the heat to the attached PCM, then the melted PCM makes a channel for the liquid PCM to form natural convection. With increasing time, the heated liquid flowed to the upper region of the PCM container, due to the natural convection, the upper front region of the RT27 then began to melt more quickly than the lower front region where the solar cells were mounted with heat source. This can be clearly seen at times $300,400,500$, and 600 mins in Figure 11. Therefore, the average temperature of solar cells can be maintained in steady and low value (as shown in Figure 9). At times 250mins and $300 \mathrm{mins}$, it can be seen that the temperatures of a portion of the solid RT27 PCM at the inner central region of the PCM container were lower than the rest of the PCM, because the heat transferred into the RT27 from the heated solar cells in the front and some heat transferred through the rear aluminium back plate from the hot ambient air also. At 400mins and 500mins, more hot liquid PCM floated up and most of upper region was filled with liquid PCM. The back aluminium plate got heat from the top region and transferred to bottom side, which melted the PCM adjacent to the plate, which can be clearly seen at 600 mins, when the phase change process is nearly complete, with only a small region of solid RT27 remaining at the back bottom corner inside the PCM container, as shown in Figure 11 at $t=600$ mins. The main region is occupied by liquid PCM and the influence of phase change process weakened, the temperatures of solar cells and aluminium plate began to increase after 600 mins.

The measured short circuit current, open circuit voltage, maximum power output, fill factor and electrical conversion efficiency of the BFI-ACP-PV system and the BFI-ACP-PV $/ P C M$ system at incident solar radiation intensity of $280 \mathrm{~W} / \mathrm{m}^{2}$ are presented in Table 5 . It can be seen that the electrical conversion efficiency of the BFI-ACP-PV system was over $5 \%$ higher, when the PCM unit was coupled to the BFI-ACP-PV system compared to the BFIACP-PV system with no PCM unit.

When the solar incidence radiation is $680 \mathrm{~W} / \mathrm{m}^{2}$, the solar cell temperatures for the BFI-ACP-PV system when combined with the PCM unit was reduced by $18^{\circ} \mathrm{C}$, compared to the BFI-ACP-PV system with no PCM unit. The predicted electrical conversion efficiency of the BFI-ACP-PV /PCM system would then increase by approximately $10 \%$ when compared to that of the BFI-ACP-PV with no RT27 PCM.

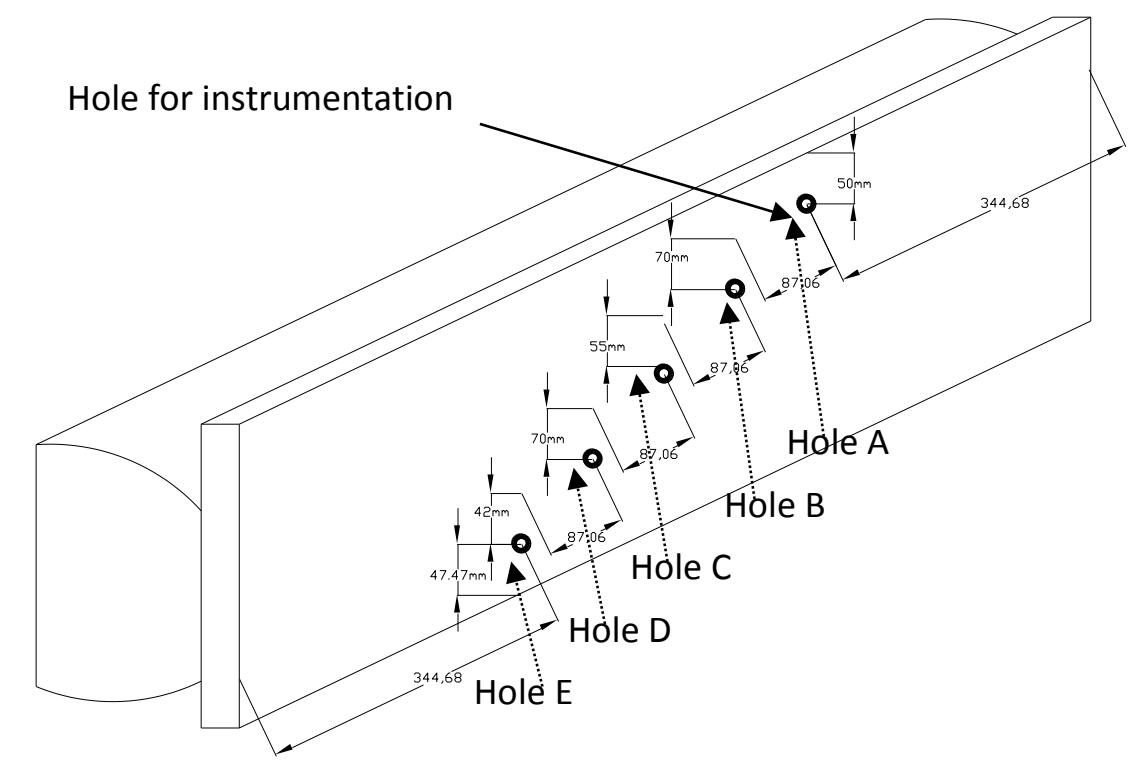

Figure $7 \mathrm{~A}$ 3D diagram of the BFI-ACP-PV /PCM system illustrating the thermocouple insertion holes, all dimensions in 'mm'. 


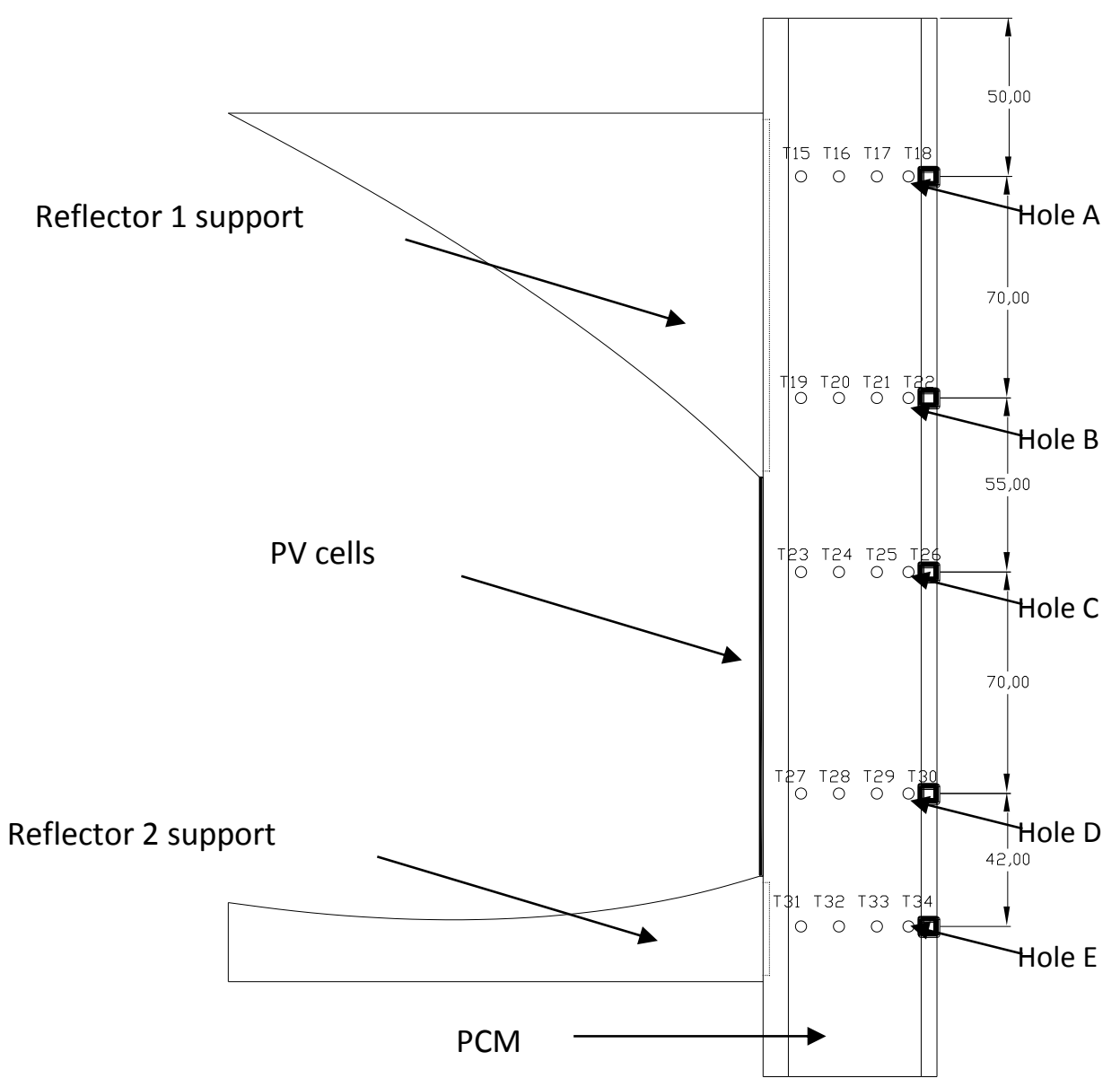

Figure 8 A cross-sectional view illustrating the locations of the thermocouples T15 to T34 inside the PCM container, all dimensions in ' $\mathrm{mm}$ '.

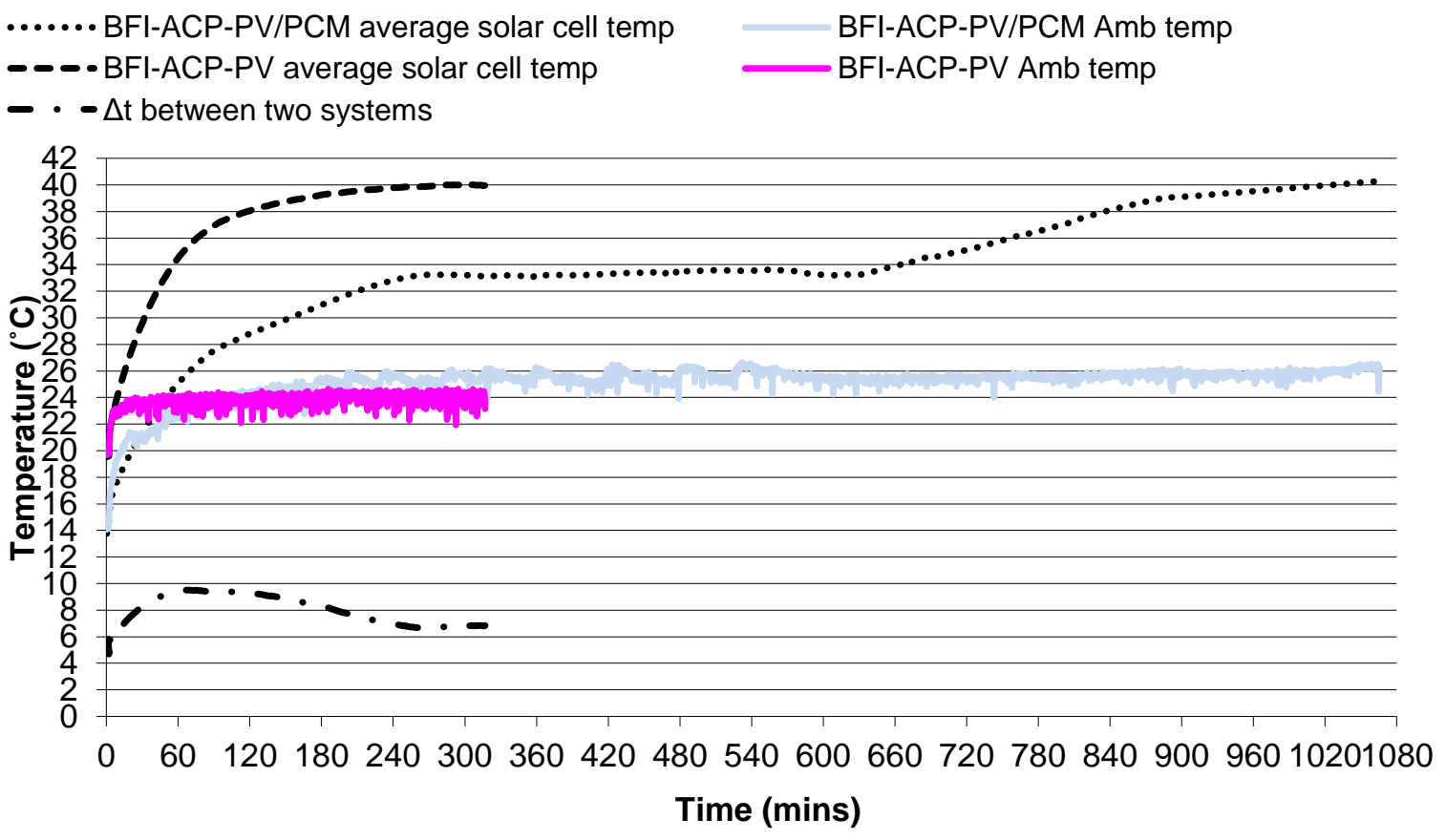

Figure 9 Measured average solar cell temperature with time for the BFI-ACP-PV and BFIACP-PV /PCM system with incident solar radiation of $280 \mathrm{~W} / \mathrm{m}^{2}$ and incidence angle of $0^{\circ}$ 
- - $\Delta$ t between two systems

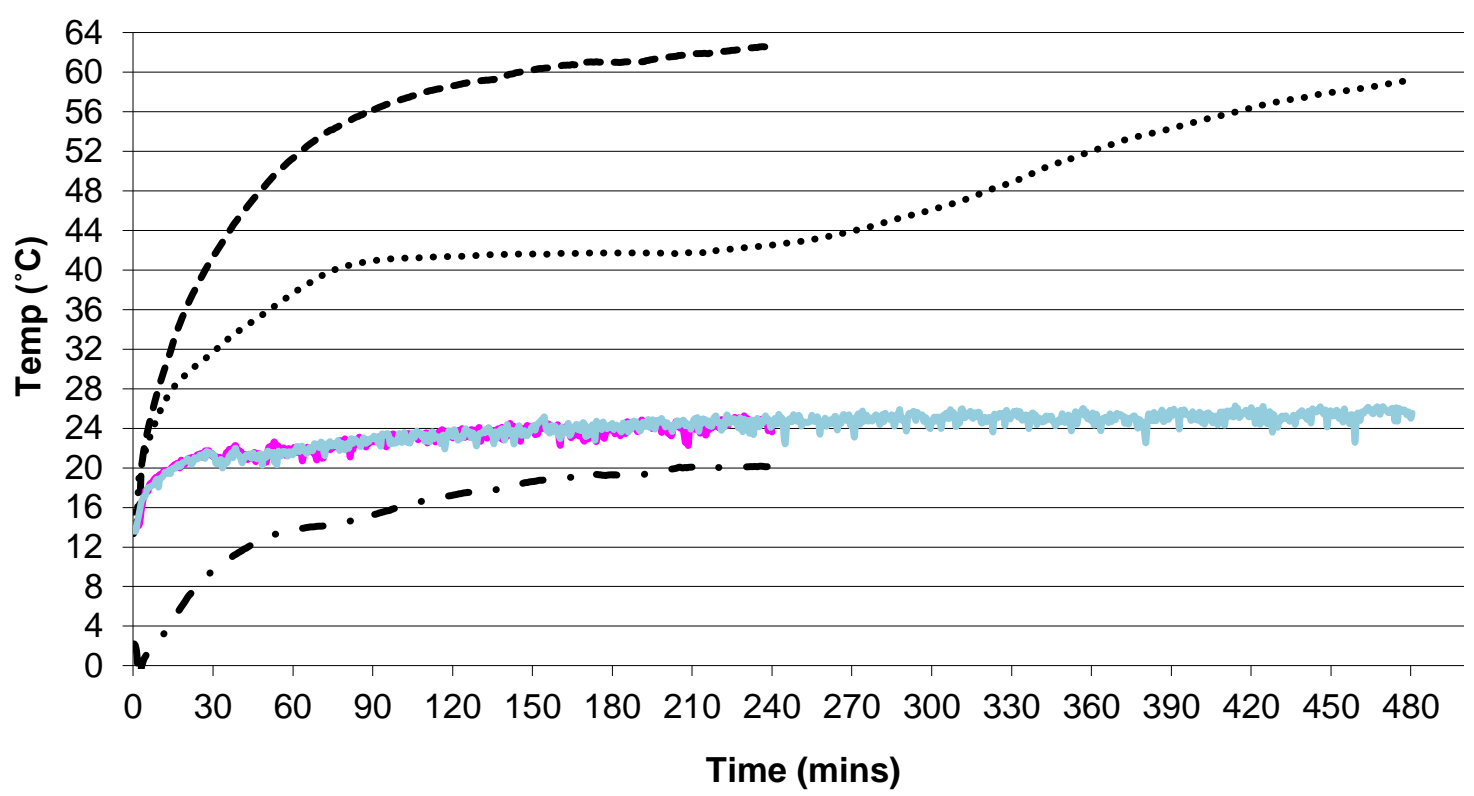

Figure 10 Measured average solar cell temperatures with time for the BFI-ACP-PV and BFIACP-PV/PCM system with incident solar radiation of $670 \mathrm{~W} / \mathrm{m}^{2}$ and incidence angle of $0^{\circ}$ 


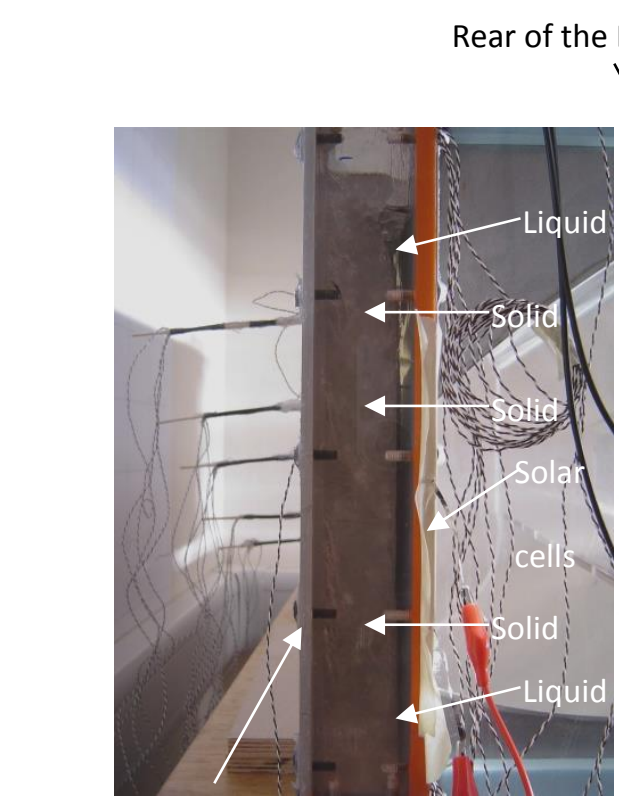

Rear of the BFI-ACP-PV /PCM

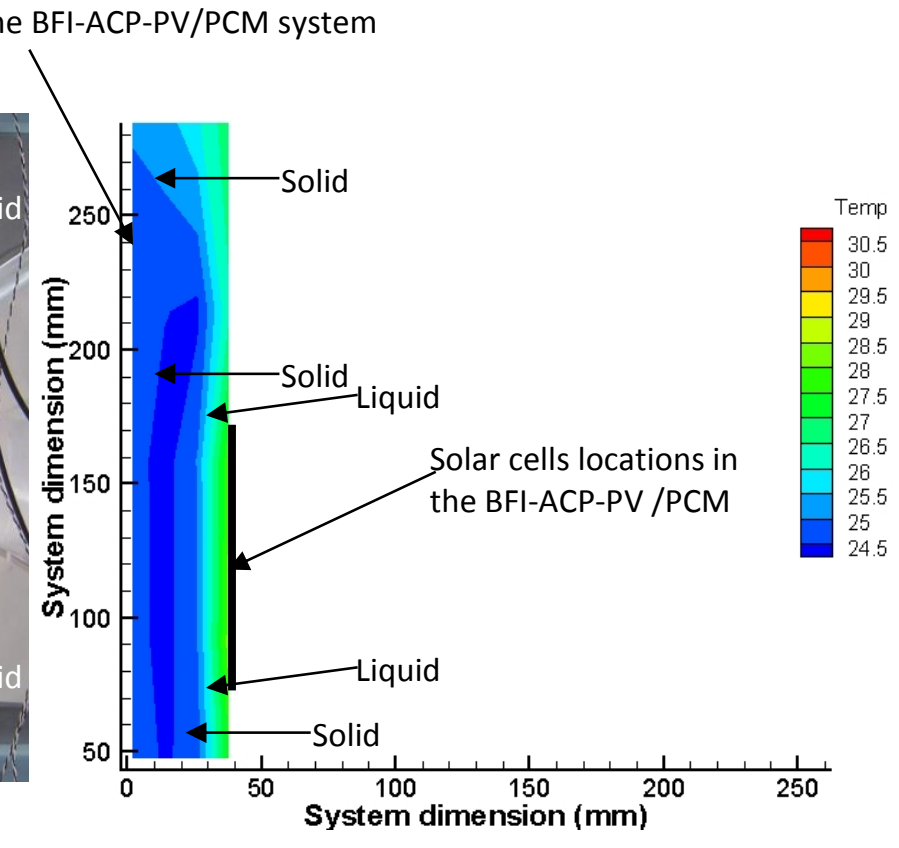

$\mathrm{t}=250 \mathrm{mins}$

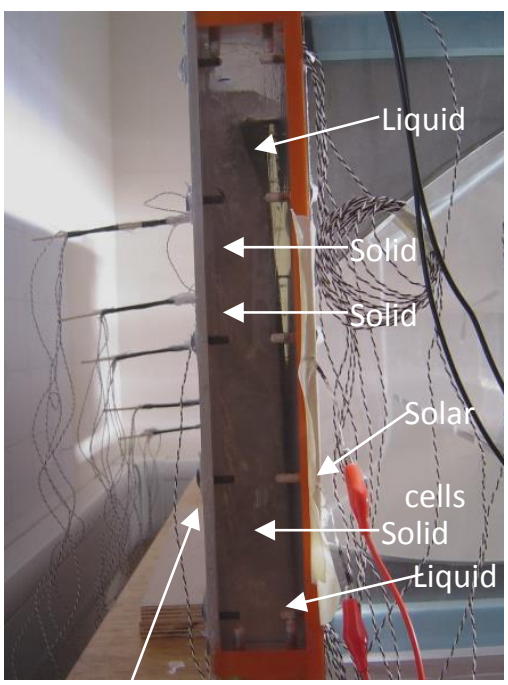

Rear of the BFI-ACP-PV /PCM system

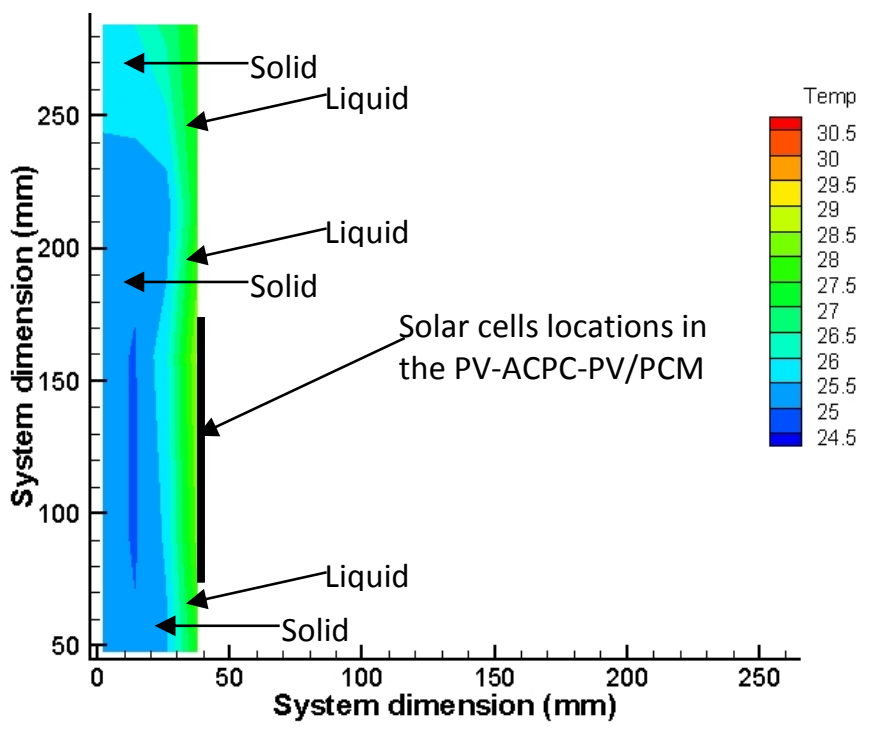

$\mathrm{t}=300 \mathrm{mins}$ 


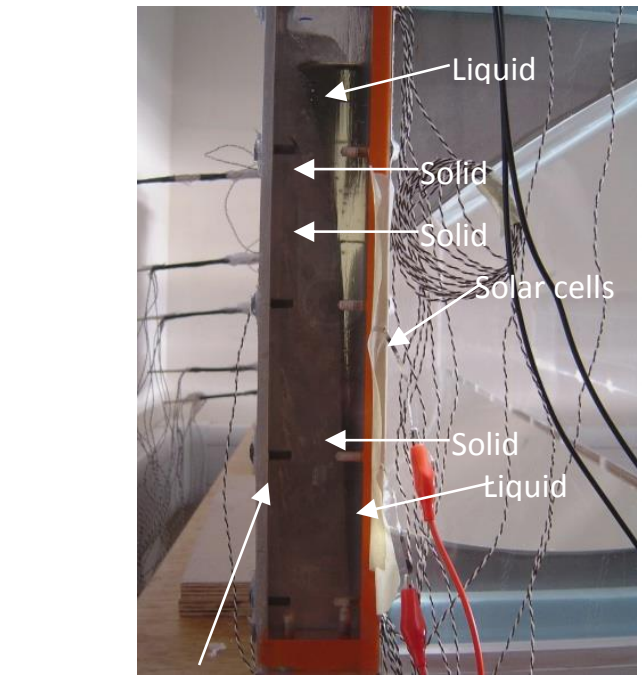

Rear of the BFI-ACP-PV /PCM system

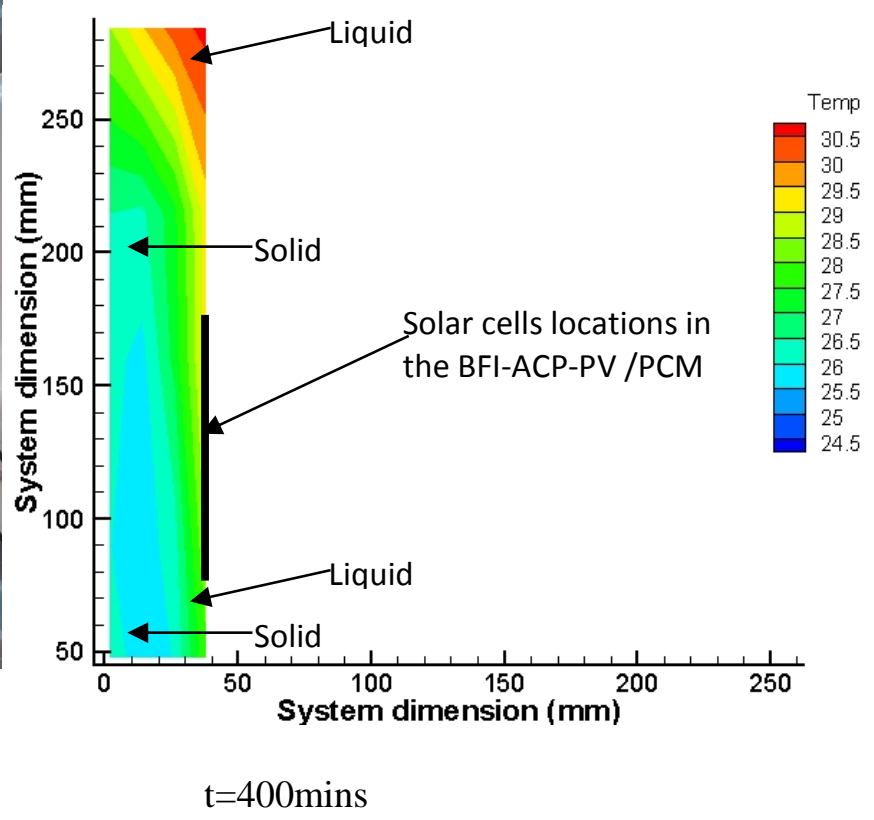

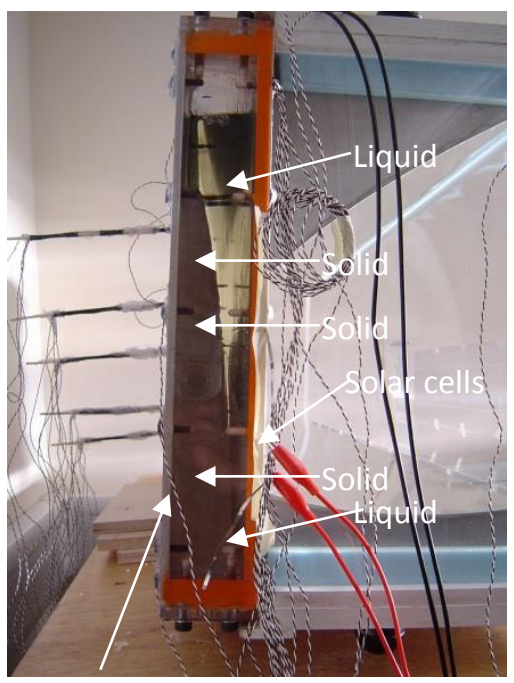

Rear of BFI-ACP-PV /PCM system

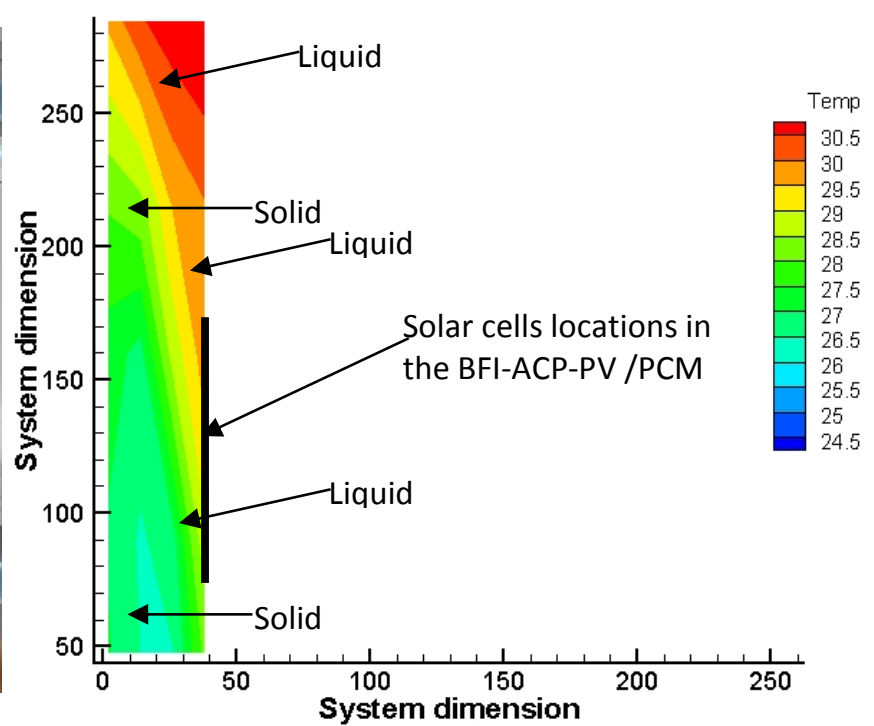

$\mathrm{t}=500 \mathrm{mins}$ 


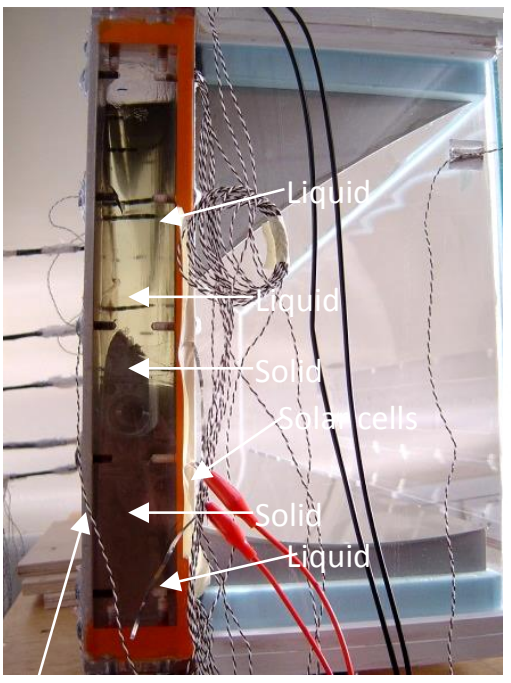

Rear of the BFI-ACP-PV/PCM system

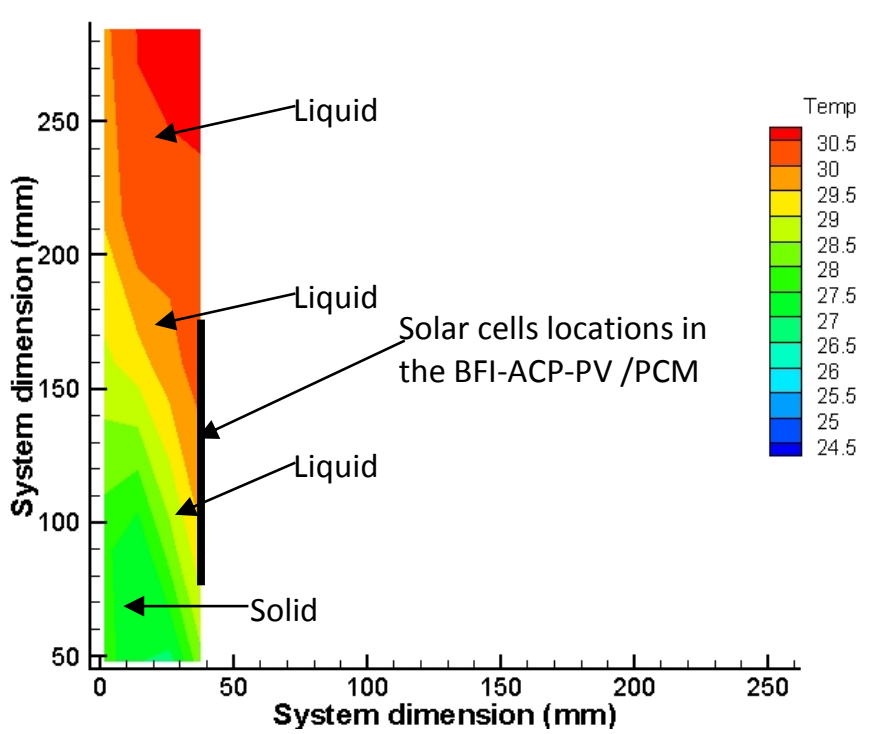

$\mathrm{t}=600 \mathrm{mins}$

Figure 11 Photographs and measured isotherms illustrating the phase change process in the PCM of the BFI-ACP-PV/PCM system for selected times when the average insolation was $280 \mathrm{~W} / \mathrm{m}^{2}$ and solar incidence angle was $0^{\circ}$.

Table 5 The measured power output of the BFI-ACP-PV and BFI-ACP-PV/PCM system after illumination using the developed solar simulator at an average solar radiation intensity of $280 \mathrm{~W} / \mathrm{m}^{2}$ for $250 \mathrm{mins}$

\begin{tabular}{c|c|c}
\hline & BFI-ACP-PV & BFI-ACP-PV /PCM \\
\hline Isc $(\mathrm{A})$ & 1.77 & 1.74 \\
\hline Voc $(\mathrm{V})$ & 3.21 & 3.30 \\
\hline MPP $(\mathrm{W})$ & 3.51 & 3.70 \\
\hline$f f$ & 0.618 & 0.644 \\
\hline$\eta(\%)$ & 13.4 & 14.1 \\
\hline Ave Cell Temp $\left({ }^{\circ} \mathrm{C}\right)$ & 40.2 & 32.5 \\
\hline
\end{tabular}

\section{Temperature dependency of solar to electrical conversion efficiency for the BFI-} ACP-PV

The measured I-V characteristics of the BFI-ACP-PV at difference solar cell temperatures for a solar incidence angle of $0^{\circ}$ and incident solar radiation intensity of $280 \mathrm{~W} / \mathrm{m}^{2}$ are shown in Figure 12. From Figure 12, it can be seen that the maximum power and open circuit voltage decrease with increasing solar cell temperature. When the average solar cell temperature was $24.5^{\circ} \mathrm{C}$, an open circuit voltage of $3.41 \mathrm{~V}$ is measured. Increasing the solar cell temperature by $8^{\circ} \mathrm{C}$, reduced the open circuit voltage by $0.11 \mathrm{~V}$.

The fill factors of the BFI-ACP-PV system at solar incidence angles of $0^{\circ}$ at different solar cell temperatures are shown in Figure 13. From Figure 13, it can be seen that the fill factor decreases with increasing solar cell temperature. The fill factors at different solar cell temperatures along with a linear line fit are also shown in Figure 13. For a solar radiation incidence angle of $0^{\circ}$, the fill factor decreased by 0.002 for every $1^{\circ} \mathrm{C}$ rise in solar cell temperature. 


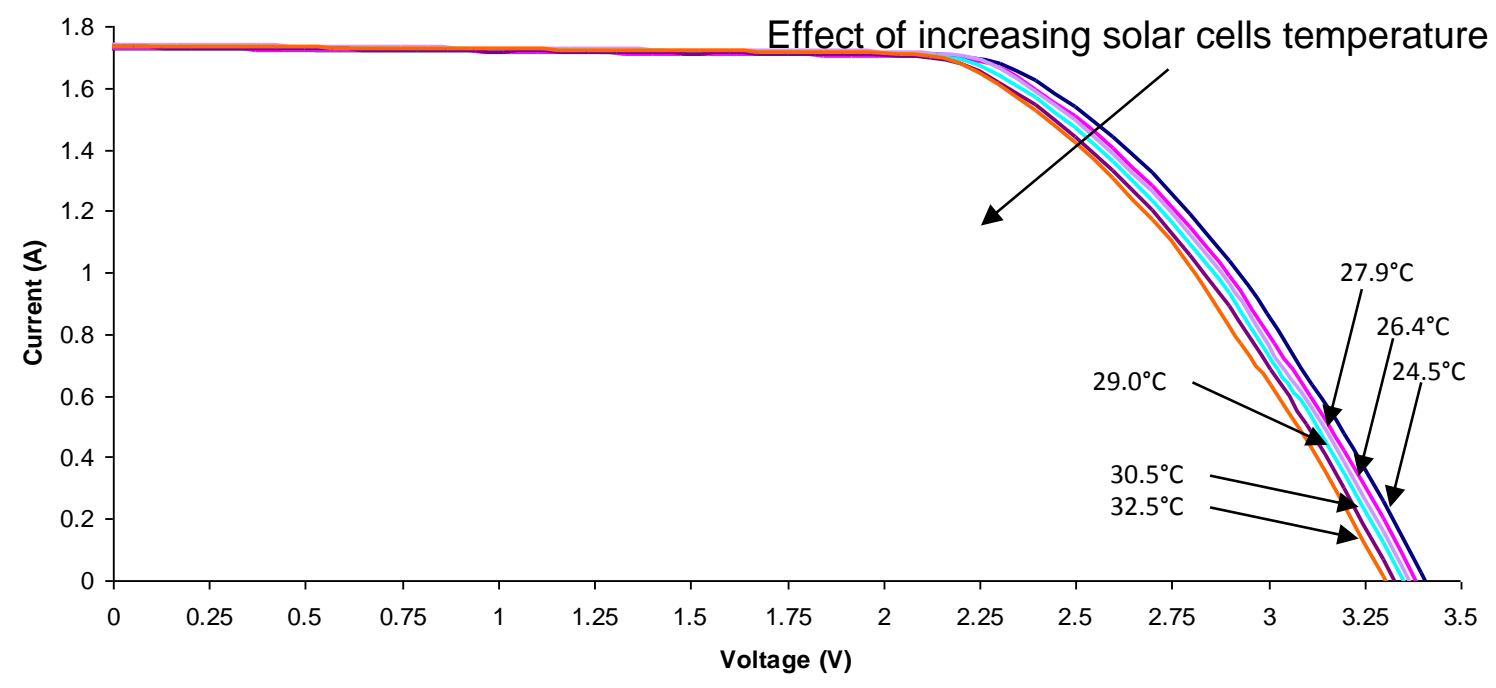

Figure 12 I-V characteristics of the BFI-ACP-PV system for different solar cell temperatures at a solar radiation intensity of $280 \mathrm{~W} / \mathrm{m}^{2}$ and solar incidence angle of $0^{\circ}$

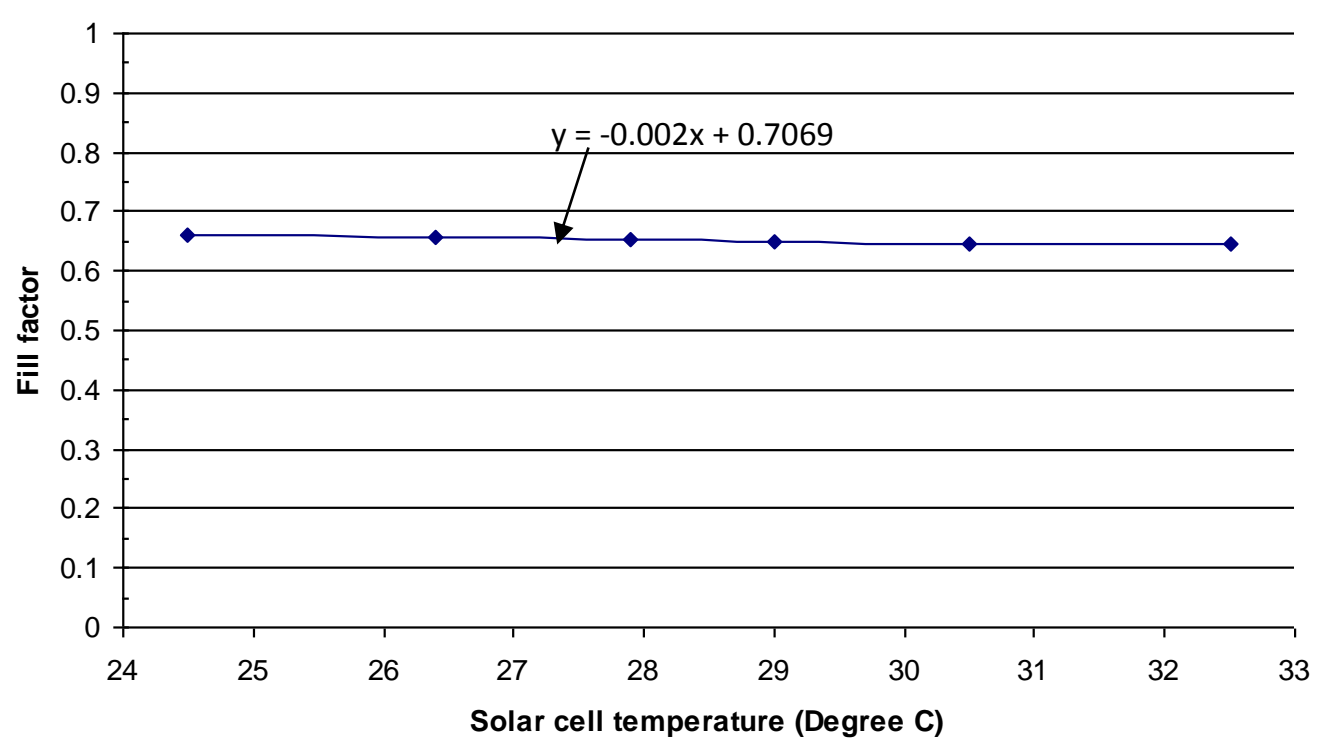

Figure 13 The variation of fill factor with solar cell temperature for the BFI-ACP-PV system under incident solar radiation intensity of $280 \mathrm{~W} / \mathrm{m}^{2}$

The electrical conversion efficiency of the BFI-ACP-PV system with different average solar cell temperature at a solar radiation intensity of $280 \mathrm{~W} / \mathrm{m}^{2}$ and an incidence angles of $0^{\circ}$ are shown in Figure 14. From Figure 14, it can be seen that the electrical conversion efficiencies decrease with increasing solar cell temperatures. When the average solar cell temperature was around $24.5^{\circ} \mathrm{C}$, the efficiency was $14.9 \%$. The efficiency decreased to $14.1 \%$ when the solar cell temperature increased to $32.5^{\circ} \mathrm{C}$. The electrical conversion efficiency decreases by approximately $6.3 \%$ for every $10^{\circ} \mathrm{C}$ rise in solar cell temperature. For crystalline silicon cells, the cell efficiency decreases by approximately $5 \%$ with a $10^{\circ} \mathrm{C}$ temperature increase. The BFI-ACP-PV system had a higher efficiency decrease with increasing the solar cell temperature, this was possibly caused by the temperature differences across the solar cells and non-uniform flux distributions. 


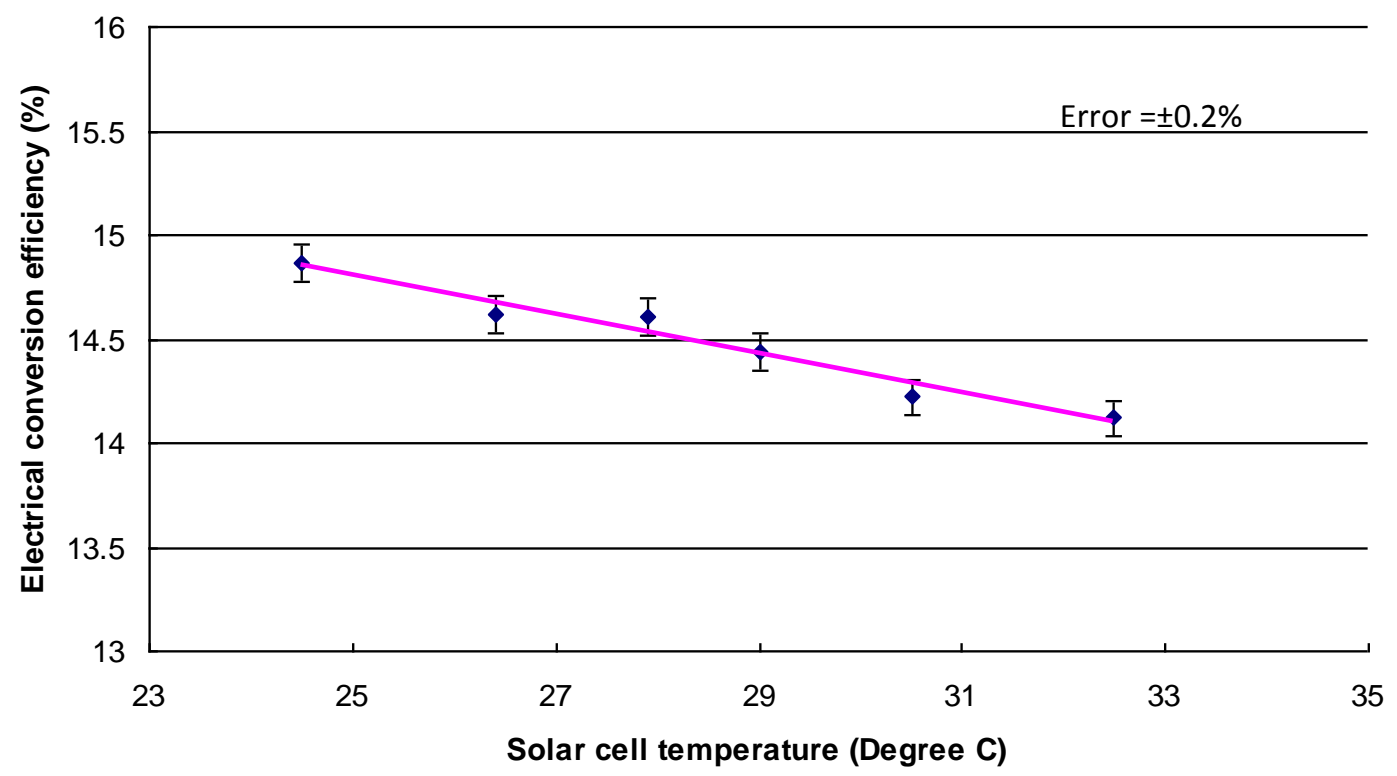

Figure 14 The variation of electrical conversion efficiency for the BFI-ACP-PV system with different solar cell temperature for solar incident radiation intensity of $280 \mathrm{~W} / \mathrm{m}^{2}$.

\section{Analysis of the electrical power losses for the BFI-ACP-PV}

For a concentration ratio of 2.0 , the effective solar radiation intensity at the absorber should increase by a factor of 2.0, if the geometry was perfect and no reflection losses occur. This implies that the maximum power point of the BFI-ACP-PV system can be double compared to its non-concentrating counterpart PV system. The maximum power ratio between the two systems was less than 2.0 at solar radiation intensities of $69 \mathrm{~W} / \mathrm{m}^{2}$ and $280 \mathrm{~W} / \mathrm{m}^{2}$. This indicates significant additional losses for the BFI-ACP-PV system, which may be caused by the non-uniform solar radiation distribution on the solar cells surface, higher solar cell temperature, non-uniform solar cell temperatures, increased resistance loss from the PV ribbon and cables and reflection losses at the reflectors. The power losses in BFI-ACP-PV system are discussed in the following paragraphs.

\subsection{Optical losses}

Power losses occur for the BFI-ACP-PV system due to optical losses in the system at the aperture cover glass, the reflectors and that resulting from the solar radiation incidence angle due to the cosine effect. The prediction of optical performance of the BFI-ACP-PV was presented in another paper [32] and showed that the maximum predicted optical efficiency of the BFI-ACP-PV system was $88.67 \%$. At a solar radiation incidence angle of $0^{\circ} \mathrm{C}$, the predicted power loss of the BFI-ACP-PV system due to optical losses in the system was approximately $12 \%$, which was approximately twice higher than that of its non-concentrating counterpart system.

\subsection{Ohmic losses in electrical cables}

Ohmic losses occur due to the resistance in the external cables used to connect the BFIACP-PV system and the Keithley 2430 source meter, and the internal connections (PV ribbons) between the individual solar cells. If the system total resistance is ' $r$ ' and the system current output is ' $\mathrm{i}$ ', then the power loss is $\mathrm{i}^{2} \mathrm{r}$. The power loss from external cables was verified by experimental tests on one BP Saturn solar cell (dimension $125 \mathrm{~mm} \times 125 \mathrm{~mm}$ ) connect to the Keithley 2430 source meter using different lengths of external cables at solar radiation intensities of $137 \mathrm{~W} / \mathrm{m}^{2}$ and $240 \mathrm{~W} / \mathrm{m}^{2}$, respectively. The systems tested are described below:

- One solar cell connected to Keithley 2430 source meter using a total length of $4.6 \mathrm{~m}$ of external cables which were the same as the cables used for the BFI-ACP-PV system 
- One solar cell connected to a Keithley 2430 source meter with a total length of $2.0 \mathrm{~m}$ of external cable

Figure 15 shows the variation of the current with the voltage for one solar cell when tested at solar radiation intensities of $137 \mathrm{~W} / \mathrm{m}^{2}$ and $240 \mathrm{~W} / \mathrm{m}^{2}$. The maximum power output and the fill factors are presented in Table 6. From Figure 15 and Table 6, it can be seen that there are no significant differences in short circuit current and open circuit voltage for the solar cell connected with $2.0 \mathrm{~m}$ and $4.6 \mathrm{~m}$ of long external cables at the same solar radiation intensity level. However, the solar cell connected with the $4.6 \mathrm{~m}$ long external cable has a reduced maximum power output than when connected with $2.0 \mathrm{~m}$ long external cable. The solar cell has a decrease of $9 \%$ in its maximum power output when connected with the $4.6 \mathrm{~m}$ long external cable, compared to being connected with the $2.0 \mathrm{~m}$ long external cable for an incident solar radiation intensity of $137 \mathrm{~W} / \mathrm{m}^{2}$, and has a decrease of approximately $13 \%$ for an incident solar radiation intensity of $240 \mathrm{~W} / \mathrm{m}^{2}$.

The measured resistance of the $4.6 \mathrm{~m}$ long external cable used for the BFI-ACP-PV and its non-concentrating counterpart systems is approximately $0.40 \Omega$. When the incident solar radiation intensity was $280 \mathrm{~W} / \mathrm{m}^{2}$, power losses of $1.28 \mathrm{~W}$ and $0.48 \mathrm{~W}$ caused by ohmic losses in the external cable were calculated from ' $\mathrm{i}^{2} \mathrm{r}$ ' for the BFI-ACP-PV and its nonconcentrating counterpart systems, respectively. An additional power loss of approximately $30.3 \%$ of that for the BFI-ACP-PV system was obtained, when compared to its nonconcentrating counterpart system at an incident solar radiation intensity of $280 \mathrm{~W} / \mathrm{m}^{2}$. Mallick et al [37] also indicated an average of 3.4\% electrical power loss of a non-concentrating PV system may be due to resistance in the interconnections between each individual solar cell. It can be concluded that the power loss due to the resistance of the measuring circuit is significant, and increases with increasing incident solar radiation intensity.

Cable length of $2 \mathrm{~m}$, solar intensity of $137 \mathrm{~W} / \mathrm{m}^{\wedge} 2$ Cable length of $4.6 \mathrm{~m}$, solar intensity of $137 \mathrm{~W} / \mathrm{m}^{\wedge} 2$

Cable length of $2 \mathrm{~m}$, solar intensity of $240 \mathrm{~W} / \mathrm{m}^{\wedge} 2=$ Cable length of $4.6 \mathrm{~m}$, solar intensity of $240 \mathrm{~W} / \mathrm{m}^{\wedge} 2$

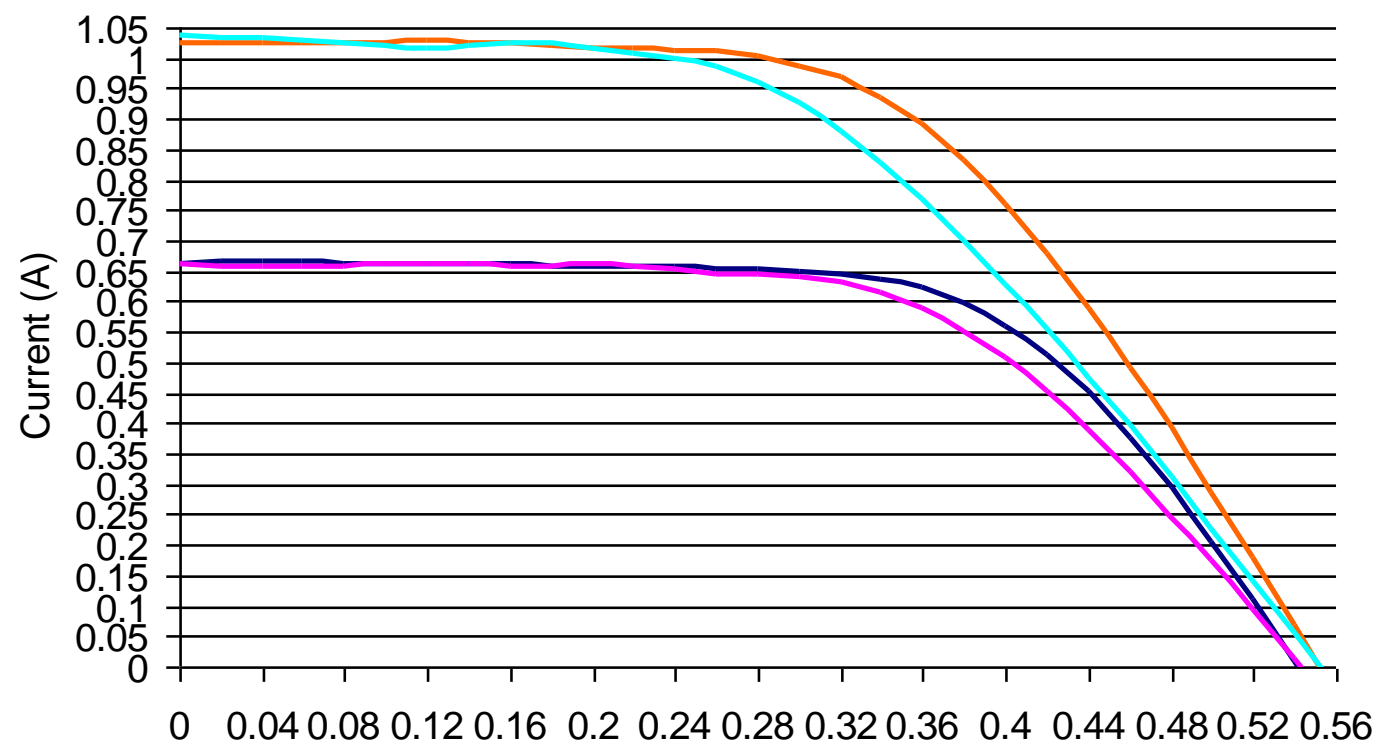

Voltage (V)

Figure $15 \mathrm{I}-\mathrm{V}$ characteristics of one solar cell with different external cable lengths for solar radiation intensities of $137 \mathrm{~W} / \mathrm{m}^{2}$ and $240 \mathrm{~W} / \mathrm{m}^{2}$. 
Table 6 The fill factors and maximum power points for a solar cell tested using different external cable lengths and solar radiation intensities.

\begin{tabular}{c|c|c|c|c}
\hline & $\begin{array}{c}\text { Cable length } \\
\text { of } 2 \mathrm{~m}, \\
\text { insolation } \\
137 \mathrm{~W} / \mathrm{m}^{2}\end{array}$ & $\begin{array}{c}\text { Cable length } \\
\text { of } 4.6 \mathrm{~m}, \\
\text { insolation } \\
137 \mathrm{~W} / \mathrm{m}^{2}\end{array}$ & $\begin{array}{c}\text { Cable length } \\
\text { of } 2 \mathrm{~m}, \\
\text { insolation } \\
240 \mathrm{~W} / \mathrm{m}^{2}\end{array}$ & $\begin{array}{c}\text { Cable length } \\
\text { of } 4.6 \mathrm{~m}, \\
\text { insolation } \\
240 \mathrm{~W} / \mathrm{m}^{2}\end{array}$ \\
\hline Fill Factor $(\%)$ & 63.2 & 59.4 & 57.0 & 49.4 \\
\hline Max power point & 0.23 & 0.21 & 0.32 & 0.28 \\
\hline
\end{tabular}

\subsection{Power losses caused by high local radiation intensities}

The electrical power loss of the BFI-ACP-PV system may be caused by the high local radiation intensity that occurred as a strip on the solar cells. It was tested by performing experiments in which a solar cell was exposed to radiation with and without a high intensity flux strip on its surface, in both experiments similar area weighted average incident solar radiation intensity was used. A mask was fabricated specifically for this test using two overlapped $400 \mathrm{~mm}$ long by $200 \mathrm{~mm}$ wide aluminium mesh sheets with a $150 \mathrm{~mm}$ long by $10 \mathrm{~mm}$ wide slot cut in their centre region sandwiched between two pieces of $6 \mathrm{~mm}$ thick Perspex sheet. Figure 16 shows an enlarged view of the solar cell under test using the developed mask. The solar concentration ratio on the solar cell surface when covered with the mask is shown in Figure 17. The radiation flux which passes through the slot in the mask and incident on the solar cell surface was approximately 5 times higher than those in other areas of the solar cell surface. The area weighted average solar concentration ratio was 1.32.

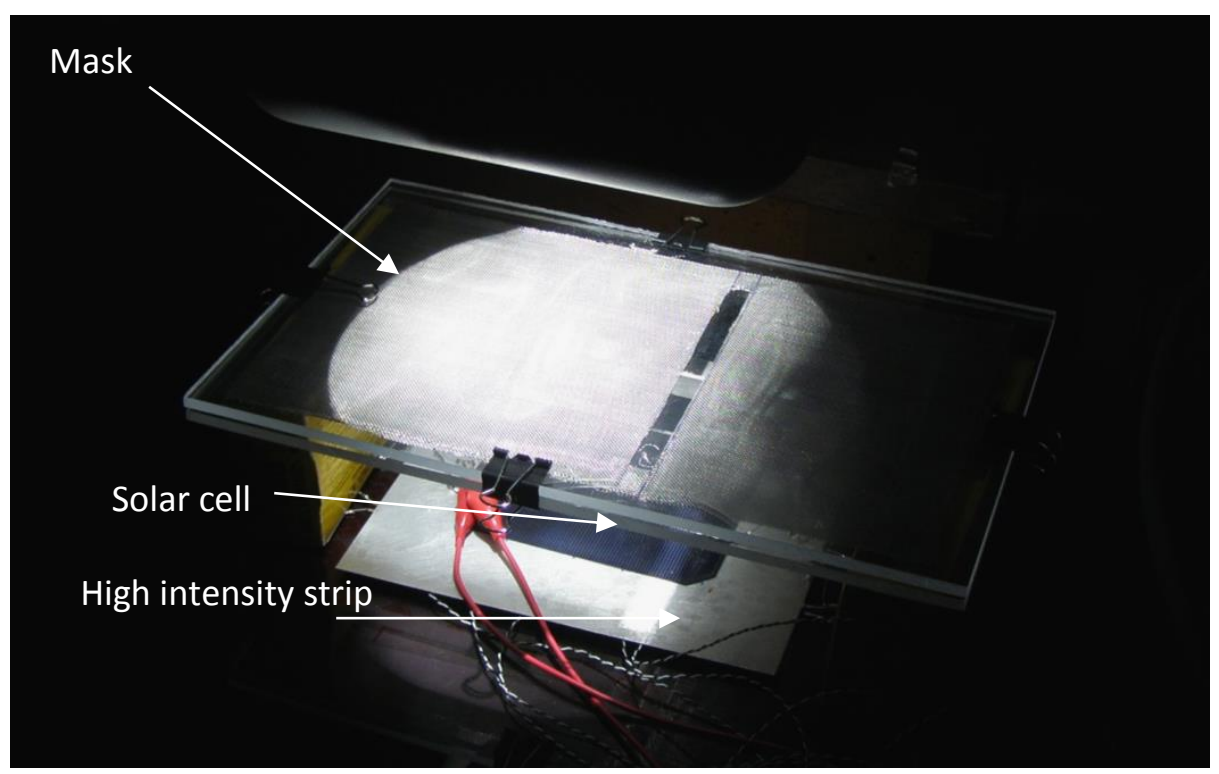

Figure 16 An enlarged view of experimental characterisation of one full size SATURN solar cell using the developed mask 


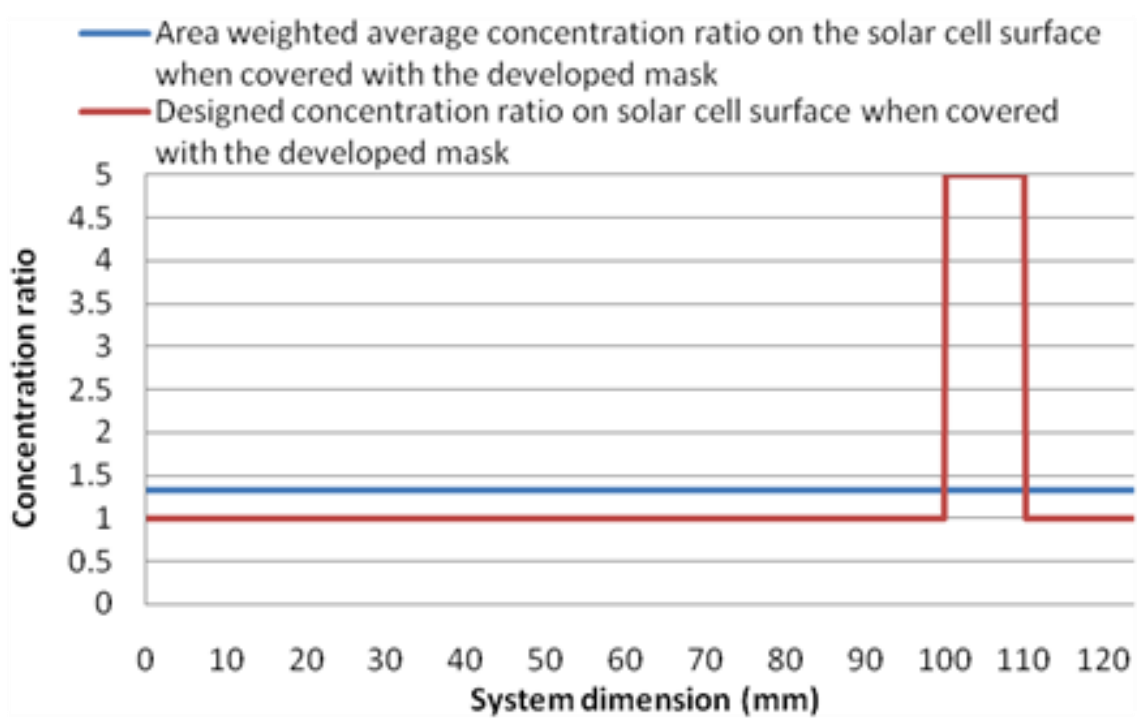

Figure 17 The concentration ratio on the solar cell surface when covered with the developed mask

Figure 18 presents that the variation of current with voltage for one solar cell with and without the high intensity flux strip. An experiment was undertaken with the area weighted average solar radiation intensity of $200 \mathrm{~W} / \mathrm{m}^{2}$. The measured short circuit currents, open circuit voltages, maximum power output and the fill factors are presented in Table 7. From Figure 18 and Table 7, it can be seen that the solar cell with no high intensity flux strip has a higher short circuit current and maximum power output than that with the high intensity flux strip. There are no significant differences for the fill factors of the solar cell with and without the high intensity strip at the same average incident radiation intensity. When the area weighted average incident solar radiation intensity is $200 \mathrm{~W} / \mathrm{m}^{2}$, a power loss of approximately $2 \%$ is found for the solar cell with a high intensity flux strip.

- Solar cell w ith high intensity flux strip, at average incident radiation intensity of $200 \mathrm{~W} / \mathrm{m}^{\wedge} 2$

Solar cell w ithout high intensity flux strip, at average incident radiation intensity of $200 \mathrm{~W} / \mathrm{m}^{\wedge} 2$

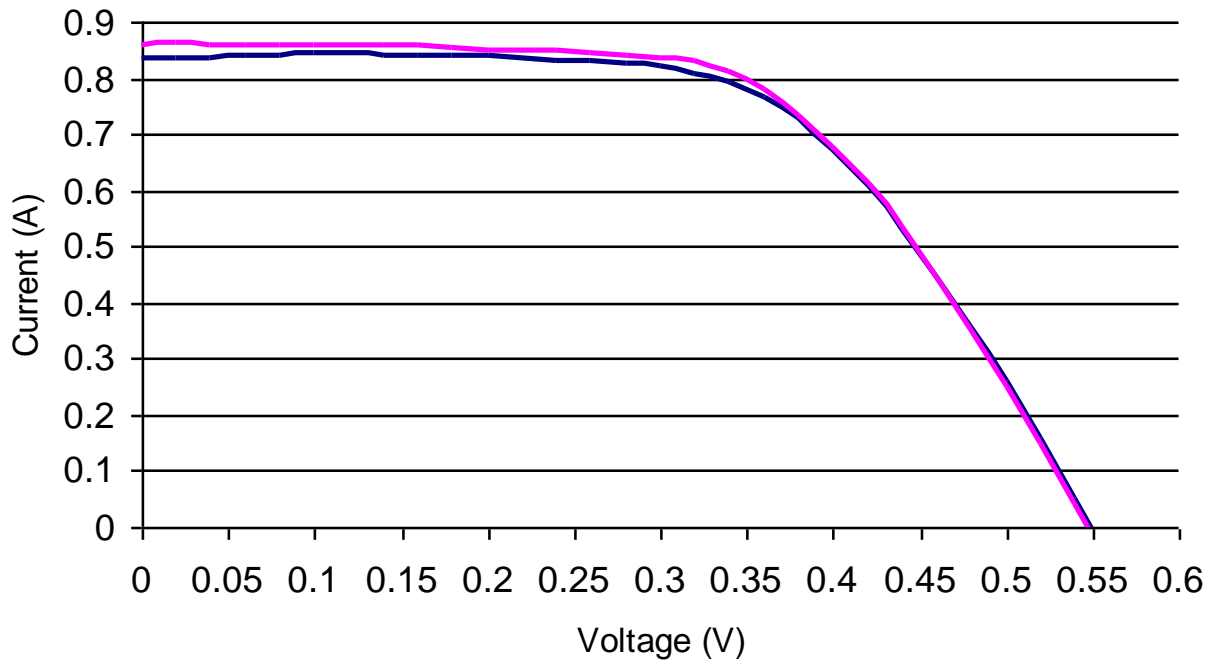

Figure $18 \mathrm{I}-\mathrm{V}$ characteristics of a solar cell for an area weighed average solar radiation intensity of $200 \mathrm{~W} / \mathrm{m} 2$ with and without high intensity strips on. 
Table 7 The short circuit currents, open circuit voltages, fill factors and maximum power points for a solar cell tested with and without high flux intensity, at an area weighted average solar radiation intensity of $200 \mathrm{~W} / \mathrm{m}^{2}$.

\begin{tabular}{c|c|c|c|c|c}
\hline & $\begin{array}{c}\text { Incident solar } \\
\text { radiation }\end{array}$ & Isc (A) & Voc (V) & MPP (W) & FF(\%) \\
\hline $\begin{array}{c}\text { Solar cell with high } \\
\text { intensity strip }\end{array}$ & $200 \mathrm{~W} / \mathrm{m}^{2}$ & 0.83 & 0.55 & 0.276 & 60.1 \\
\hline $\begin{array}{c}\text { Solar cell without high } \\
\text { intensity strip }\end{array}$ & $200 \mathrm{~W} / \mathrm{m}^{2}$ & 0.86 & 0.55 & 0.281 & 59.3 \\
\hline
\end{tabular}

\subsection{Hot spot effect}

From section 4 , it can be seen that the average solar cell temperature difference between the BFI-ACP-PV and the non-concentrating PV system was approximately $1.2^{\circ} \mathrm{C}$ and $3^{\circ} \mathrm{C}$ at solar radiation intensities of $69 \mathrm{~W} / \mathrm{m}^{2}$ and $280 \mathrm{~W} / \mathrm{m}^{2}$, respectively. With every $10^{\circ} \mathrm{C}$ increase in silicon solar cell temperature, the electrical conversion efficiency decreases by $6.3 \%$ (discussed in section 4). This implies a possible electrical conversion efficiency decreases of around $0.8 \%$ and $1.9 \%$ for the BFI-ACP-PV system when compared to the nonconcentrating PV counterpart system, at incident solar radiation intensities of $69 \mathrm{~W} / \mathrm{m}^{2}$ and $280 \mathrm{~W} / \mathrm{m}^{2}$.

\section{Conclusions}

A novel Building Façade Integrated Asymmetric Compound Parabolic Photovoltaic concentrator (BFI-ACP-PV) coupled with Phase Change Material (PCM) system (BFI-ACP$\mathrm{PV} / \mathrm{PCM}$ ) which is suitable for integration into building vertical façades has been designed and experimentally characterised. The thermal and I-V characteristics of the developed BFIACP-PV and its counterpart non-concentrating PV system were investigated under controlled indoor environmental conditions. Temperature dependency of solar to electrical conversion efficiency for the BFI-ACP-PV was also detailed analysed. Finally, a comprehensive power loss analysis of the BFI-ACP-PV system has also been undertaken. The following conclusions can be drawn:

- The power output of the BFI-ACP-PV is approximately 1.74 and 1.33 of that of its nonconcentrating counterpart system at incident solar radiation intensities of 69 and $280 \mathrm{~W} / \mathrm{m}^{2}$, respectively.

- When the BFI-ACP-PV is integrated with the PCM system, the PCM system moderated the PV temperature rise and maintained good solar-electrical conversion efficiency. The electrical conversion efficiency for the BFI-ACP-PV /PCM system was increased by over $5 \%$ compared with that with no PCM integrated at the rear, when the incident solar radiation intensity was at $280 \mathrm{~W} / \mathrm{m}^{2}$, and increased by over $10 \%$ for an incident solar radiation intensity of $670 \mathrm{~W} / \mathrm{m}^{2}$.

- When the average solar cell temperature increase from approximately $25^{\circ} \mathrm{C}$ to $33^{\circ} \mathrm{C}$, the open circuit voltage decreased by $0.11 \mathrm{~V}$. Meanwhile, the electrical conversion efficiency decreased by approximately $6.3 \%$ for every $10^{\circ} \mathrm{C}$ rise in solar cell temperature, this value is higher than that of a common silicon based solar cell without concentrating system.

- It was found that there is a potential approximately $6 \%$ power loss due to the lower optical efficiency of the BFI-ACP-PV system, when compared with the non-concentrator counterpart system, in addition, a high intensity flux strip probably caused a power loss of approximately $2 \%$ for the solar cells, meanwhile the solar cell temperature difference produced by the concentrator implied a further $2 \%$ decrease in solar to electricity conversion efficiency, however, the majority of the power loss is caused by the ohmic losses occur due to the resistance in the external cables used to connect the BFI-ACPPV system and the Keithley 2430 source meter. 


\section{References}

[1] Ratismith, W., Favre, Yann., Canaff, M., Briggs, J. (2017) A non-tracking concentrating collector for solar thermal applications, Applied Energy, Vol.200, pp. 39 - 46

[2] Winston, R., Miñano J. C. and Benítez, P. (2005) Nonimaging Optics. London U.K Elsevier Academic Press.

[3] Brinkworth, B. J, Cross, B. M., Marshall, R.H. and Yang, H (1997) Thermal regulation of photovoltaic cladding. Solar Energy, Vol.61, pp. 169-178.

[4] Brinkworth, B. J. and Sandberg, M. (2006) Design procedure for cooling ducts to minimise efficiency loss due to temperature rise in PV arrays. Solar Energy, Vol.80, pp. 89103.

[5] Tonui, J.K. and Tripanagnostopoulos,Y. (2007) Improved PV/T solar collectors with heat extraction by forced or natural air circulation. Renewable Energy, Vol.32, pp. 623-637.

[6] Huang, M. J., Eames, P.C. and Norton, B. (2004) Thermal regulation of buildingintegrated photovoltaics using phase change materials. International Journal of Heat and Mass Transfer, Vol. 47, pp 2715-2733.

[7] Tian, Y., Zhao, C.Y.(2013) A review of solar collectors and thermal energy storage in solar thermalapplications Applied Energy, Vol.104, pp. 538 - 553

[8] Moshfegh, B and Sandberg, B. (1998) Flow and heat transfer in the air gap behind photovoltaic panels. Renewable and Sustainable Energy Reviews, Vol.2, pp. 287-301

[9] Brinkworth, B. J. (2006) Optimum depth for PV cooling ducts. Solar Energy, Vol.80, pp. 1131-1134.

[10] Garg, H. P. and Adhikari, R. S. (1998) Transient simulation of conventional hybrid photovoltaic/thermal(PV/T) air heating collectors. International Journal of Energy Research, Vol.22, pp. 547-562.

[11] Garg, H. P. and Adhikari, R. S. (1999) System performance studies on a photovoltaics/ thermal (PV/T) air heating collector. Renewable Energy, Vol. 16, pp. 725-730.

[12] Tripanagnostopoulos, Y., Nousia, Th., Soluiotis, M. and Yianoulis, P. (2002) Hybrid photovoltaic/ thermal solar systems. Solar Energy, Vol.72, pp. 217-234.

[13] Huang, M. J., Eames, P.C. and Norton, B. (2006) Phase change materials for limiting temperature rise in building integrated photovoltaics. Solar Energy, Vol. 80, pp 1121-1130.

[14] Huang, M. J., Eames, P.C. and Norton, B. (2006) Comparison of a small-scale 3D PCM thermal control model with a validated 2D PCM thermal control model. Solar Energy Materials and Solar Cells, Vol.90, pp. 1961-1972.

[15] A. Hasan, S.J. McCormack, M.J. Huang, B. Norton (2010) Evaluation of phase change materials for thermal regulation enhancement of building integrated photovoltaics, Solar Energy, Vol 84, pp. 1601-1612,

[16] P.H. Biwole, P. Eclache, F. Kuznik (2013) Phase-change materials to improve solar panel's performance, Energy and Buildings, Vol 62, pp. 59-67.

[17] J. Park, T. Kim, S.B. Leigh (2014) Application of a phase-change material to improve the electrical performance of vertical-building-added photovoltaics considering the annual weather conditions, Solar Energy, Vol.105, pp. 561-574.

[18] A. Hasan, S.J. McCormack, M.J. Huang, J. Sarwar, B. Norton (2015) Increased photovoltaic performance through temperature regulation by phase change materials: materials comparison in different climates. Solar Energy, Vol 115, pp. 264-276.

[19] M.C. Browne, B. Norton, S.J. McCormack (2016) Heat retention of a photovoltaic/thermal collector with PCM, Solar Energy, Vol. 133, pp. 533-548.

[20] Li W. Hao Y., Explore the performance limit of a solar PV - thermochemical power generation system, Applied Energy 206 (2017) 843 - 850

[21] Chen H., Zhang L, Jie P., Xiong Y., Xu P., Zhai H., (2017) Performance study of heatpipe solar photovoltaic/thermal heat pump system, Applied Energy Vol.190, pp. 960-980

[22] Qiu Z., Ma X., Zhao X., Li P., Ali S., (2016) Experimental investigation of the energy performance of a novel Micro-encapsulated Phase Change Material (MPCM) slurry based PV/T system Applied Energy Vol. 165, pp. 260-271 
[23] Maiti, S., Banerjee, S., Vyas, K., Patel, P., and Ghosh P. K., (2011) Self regulation of photovoltaic module temperature in $\mathrm{V}$-trough using a metal-wax composite phase change matrix, Vol 85, pp. 1805-1816.

[24] Emam, M., Ookawara, S., and Ahmed, M., (2017) Performance study and analysis of an inclined concentrated photovoltaic-phase change material system, Vol 150, pp. 229-245.

[25] Emam, M. and Ahmed, M., (2018) Cooling concentrator photovoltaic systems using various configurations of phase-change material heat sinks, Vol 158, pp. 298-314.

[26] Su Y., Zhang, Y., and Shu L., (2018) Experimental study of using phase change material cooling in a solar tracking concentrated photovoltaic-thermal system, Solar Energy. Vol 159, pp. 777-785.

[27] S. Sharma, A. Tahir, K.S. Reddy, T.K. Mallick (2016) Performance enhancement of a Building-Integrated Concentrating Photovoltaic system using phase change material. Solar Energy Materials and Solor Cells, Vol. 149, pp. 29-39,

[28] Sharma, S., Micheli, L., Chang, W., Tahir, A.A., Reddy, K. S. and Mallick T.K. (2017) Nano-enhanced Phase Change Material for thermal management of BICPV, Vol 208, pp. 719-733.

[29] Connelly, K., Wu, Y., Chen, J., Lei, Y., 2016, Design and Development of a Reflective Membrane for a Novel Building Integrated Concentrating Photovoltaic (BICPV) 'Smart Window' System, Applied Energy, 182, 331-339.

[30] Wu, Y.*, Connelly, K., Liu, Y., Gu, X., Gao, Y., and Chen, G. Z., 2016, Smart solar concentrators for building integrated photovoltaic façades, Solar Energy, 133, 111-118.

[31] Connelly, K., Wu, Y., Ma, X., Lei, Y., 2017, Transmittance and Reflectance Studies of Thermotropic Material for a Novel Building Integrated Concentrating Photovoltaic (BICPV)'Smart Window' System, Energies, 10, 1889.

[32] Wu Y., Eames P. C. and Smyth M., 2007. Optical analysis of Asymmetric Compound Parabolic Photovoltaic Concentrators (ACPPVC) suitable for building façade integration In: International Conference on Solar Concentrators for the Generation of Electricity or Hydrogen (ICSC-4).

[33] BP Solar, (2010) Madrid, Spain.

[34] Deutsche Gesellschaft Für Sonnenenergie, (2005) Planning and Installing Photovoltaic Systems: A Guide for Installers, Architects and Engineers. James \& James, London U.K.

[35] RubiTherm Technologies GmbH, Berlin, Germany.

[36] Wu. Y (2009) Thermal management of concentrator photovoltaics, PhD thesis, University of Warwick, UK.

[37] Mallick, T. K., Eames., P. C., and Norton B. (2007) Power losses in an asymmetric compound parabolic photovoltaic concentrator, Solar Energy Materials and Solar Cells, Vol. 91, pp. 1137-1146. 